\title{
Prunus avium L. (Sweet Cherry) By-Products: A Source of Phenolic Compounds with Antioxidant and Anti-Hyperglycemic Properties-A Review
}

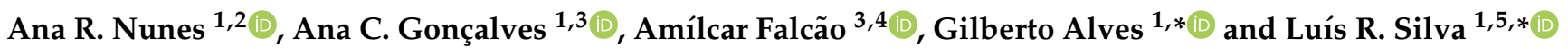 \\ 1 CICS-UBI-Health Sciences Research Centre, University of Beira Interior, Av. Infante D. Henrique, \\ 6200-506 Covilhã, Portugal; araqueln@gmail.com (A.R.N.); anacarolinagoncalves@sapo.pt (A.C.G.) \\ 2 CNC-Centre for Neuroscience and Cell Biology, Faculty of Medicine, University of Coimbra, \\ 3004-504 Coimbra, Portugal \\ 3 Laboratory of Pharmacology, Faculty of Pharmacy, University of Coimbra, Azinhaga de Santa Comba, \\ 3000-548 Coimbra, Portugal; acfalcao@ff.uc.pt \\ 4 CIBIT-Coimbra Institute for Biomedical Imaging and Translational Research, University of Coimbra, \\ Azinhaga de Santa Comba, 3000-548 Coimbra, Portugal \\ 5 CPIRN-UDI-IPG-Research Unit for Inland Development, Center for Potential and Inovation of Natural \\ Resources, Polythecnic of Guarda, 6300-554 Guarda, Portugal \\ * Correspondence: gilberto@fcsaude.ubi.pt (G.A.); luisfarmacognosia@gmail.com (L.R.S.)
}

check for updates

Citation: Nunes, A.R.; Gonçalves, A.C.; Falcão, A.; Alves, G.; Silva, L.R. Prunus avium L. (Sweet Cherry) By-Products: A Source of Phenolic Compounds with Antioxidant and Anti-Hyperglycemic Properties-A Review. Appl. Sci. 2021, 11, 8516. https://doi.org/10.3390/app11188516

Academic Editors: Gang Ma, Masaya Kato and Pongphen Jitareerat

Received: 30 July 2021

Accepted: 10 September 2021

Published: 14 September 2021

Publisher's Note: MDPI stays neutral with regard to jurisdictional claims in published maps and institutional affiliations.

Copyright: (c) 2021 by the authors. Licensee MDPI, Basel, Switzerland. This article is an open access article distributed under the terms and conditions of the Creative Commons Attribution (CC BY) license (https:// creativecommons.org/licenses/by/ $4.0 /)$.

\begin{abstract}
Prunus avium L. (sweet cherry) is one of the most appreciated fruit due to its organoleptic and nutritional value. Interestingly, cherry leaves, stems, and flowers are agri-food by-products rich in bioactive compounds that are mostly still unexploited. Stems and leaves have been used in folk medicine since ancient times. Recently, cherry flowers have also proved to be an interesting source of compounds with therapeutic properties. Phenolic compounds, namely hydroxycinnamic acids and flavonoids, are the most present phytochemicals in P. avium fruits and their by-products. These compounds have shown a good antioxidant potential to prevent oxidative stress-related diseases and glycemic control, fundamental in preventing and controlling diabetes mellitus. The present review summarizes the main phenolics found in P. avium stems, leaves, and flowers as compared to their fruits and describes their antioxidant and anti-hyperglycemic properties. Thus, these by-products are an accessible and low-cost source of bioactive constituents with interesting health-promoting properties, making their use promising in diabetes therapy.
\end{abstract}

Keywords: Prunus avium L. (sweet cherry); by-products; phenolic compounds; diabetes mellitus; biological properties

\section{Introduction}

Many plants have been used as a source of phytochemicals with excellent bioactive properties as well as health-promoting activities. Prunus avium L., commonly known as sweet cherry, is one of the most appreciated red fruits, and it is part of the Mediterranean diet [1]. Furthermore, many scientific reports have shown interesting biological effects [1,2]. The cultivation and consumption of cherries are rising globally, with Turkey, the United States of America, Uzbekistan, and Chile as the main producers [1,3]. According to the Food and Agriculture Organization (FAO) of the United Nations Statistical Database in 2018, the world production of sweet cherries was about 2,923,723 tons [4]. In Portugal, there is a long tradition of cherry cultivation, particularly in the northeast of the country, in the Cova da Beira region (Fundão). In this area, the production of cherries is at around 17,461 tons per year [5-7]. Most cherry production is for fresh consumption, although it can also be processed into other products such as juice, jam, marmalade, and toppings. Thus, this fruit production and processing lead to several by-products, which are often discarded. 
Nowadays, the valuation of by-products based on the recovery of bioactive phytochemicals from the eliminated plant material has aroused interest, namely because it has high levels of natural antioxidants and/or other constituents with biological properties [8-11]. In recent years, the identification of phenolic compounds and the evaluation of the biological potential of $P$. avium by-products have been the subject of a few studies [7,10,12-15]. Additionally, to avoid agro-wastes, special attention has been paid to their vegetal parts, including stems, leaves, and flowers, also because their infusions are largely used in traditional medicine as diuretics, sedatives, as draining and anti-inflammatory agents, and also to boost the cardiovascular system and improve smooth muscle [12,16,17].

As part of a rich and balanced diet, the phenolic compounds present in fruits and vegetables play a relevant role in promoting human health, thus being an interesting target for nutrition research. Cherry fruit and its by-products contain several of these phytochemicals, mainly anthocyanins, phenolic acids, and flavan-3-ols, which have demonstrated biological activities $[7,10,13,18]$, such as antioxidant and antidiabetic properties $[6,7]$. The literature reports compelling evidence of the benefits ascribed to the long-term consumption of phenolics in the prevention of several oxidative stress-induced diseases such as diabetes mellitus (DM) $[19,20]$. It is well-recognized that the regular consumption of fruits, vegetables, and herbal infusions is an excellent strategy for the reduction of the risk of DM. According to global estimates of the World Health Organization (WHO), the number of diabetic individuals worldwide will be about 366 million in 2030 [21]. Alarmingly, there is also a strikingly increasing trend of DM initiation, namely a prediabetic state, among children and adolescents [22]. Therefore, these facts represent a serious concern for public health, contributing to higher morbidity and mortality. Combining inner antioxidant defenses with exogenous antioxidants is crucial to prevent the oxidative damage involved in the onset of the disease. Therefore, the search for new formulations based on accessible and affordable natural products that could be used in the prevention of many ailments, including DM, has been increasing.

Considering the relevance of sweet cherry stems, leaves, and flowers from a biological and agro-economical point of view, the main purpose of this review is to address the phenolic composition of these agro by-products. Moreover, the biological potential of P. avium by-products regarding antioxidant and anti-hyperglycemic activities are described. The increase of oxidative stress is an important trigger in the development and progression of DM, so the discovery of biological activities in underexplored and valued products is attractive. Furthermore, more recently, scientific reports from our research group and others have started to unveil the remarkable effects of $P$. avium fruits and their by-products against oxidative stress-related diseases [5-7,10]. Additionally, the recovery and valuation of these by-products may be a new strategy for obtaining bioactive compounds, encouraging their incorporation in functional foods, pharmaceutical drugs, dietary supplements, and nutraceuticals, while also contributing to the circular economy.

This review is organized as follows: the second part of the review presents an overview of the origin, production, botanical characteristics, and traditional uses of P. avium. A detailed description of the phenolic composition of cherry leaves, stems, and flowers compared to cherry fruits is presented in part three. The fourth part describes the main in vitro, in vivo, and human studies on the antioxidant and anti-hyperglycemic potential of these P. avium by-products. Finally, part five concludes the paper and presents several guidelines for further research work.

\section{Prunus avium L.}

\subsection{Origin and Production}

P. avium is a diploid fruit, and its tree can reach a height of up to $15-25 \mathrm{~m}$. It is probably native to Europe and Western Asia. It is cultivated worldwide, mainly in regions with temperate climates such as the Mediterranean and Central Europe, the United States of America, Asia, and North Africa [1]. Sweet cherry cultivars mature from the end of April to June/July in the northern hemisphere. In the southern hemisphere, most sweet cherries 
are harvested in December and January. In Europe, this fruit is harvested between May and July. In Portugal, particularly in the Fundão region (Beira Interior), this fruit is very appreciated and contributes to local economic development, reaching an annual production of around 17,000 tons [23].

There are more than 100 cherry cultivars (e.g., Burlat, Saco, Summit, Sweetheart, Brooks, among others), and can be red- or yellow-fleshed [24]. Most red-fleshed sweet cherries have dark-red flesh, juice, and skin, while the yellow-fleshed sweet cherry varieties may have yellow flesh and skin with clear or yellow flesh, clear juice, and yellow skin [25].

Sweet cherry is very appreciated by consumers due to its bright color, texture, pleasant aroma and taste, and richness in several bioactive constituents [26]. In recent years, the P. avium fruit and its by-products have attracted growing interest from the scientific community because of its nutritional and bioactive composition and the consequent biological properties $[5-7,10,12,23]$.

\subsection{Botanical Characteristics}

Regarding their by-products, cherry stems are generally green due to their chlorophyll content. The color change in stems is used as an indicator for evaluating the degree of fruit freshness [27]. During the industrial processing of cherries, the stems are removed and discarded, and little attention has been paid to the valuation of these vegetal parts. On other occasions, they are used in traditional medicine for the treatment of urinary infections.

The cherry trees are subjected to pruning, promoting the generation of leaves that are normally discarded. These leaves may be ovoid-acute, glabrous matt, or sub-shiny and present a fine downy beneath a serrated margin, and an acuminate tip. In Autumn, their colors change from green to orange.

The cherry flowers appear in early Spring and fall to bear fruit without having any kind of use. They are allogamous and actinomorphic, measuring about $2-2.5 \mathrm{~cm}$ in diameter. The flowers exhibit five white petals, yellowish stamens, and a superior ovary. Moreover, they are hermaphrodites and can be pollinated by bees.

\subsection{Traditional Uses}

Since the ancient times, $P$. avium fruits and their by-products have been used in folk medicine to treat several problems/diseases, promoting health and well-being. The main focus of the therapeutic potential of cherries and their by-products is on the urinary tract, acting as a diuretic, draining, and anti-inflammatory agent $[28,29]$. The infusions and decoctions of stems or leaves promote urination and toxin elimination, which are indicated as adjuvants in the treatment of urinary infections. It also helps in the treatment of nephritis, cystitis, gallstones, and renal lithiasis [29]. Other ethnobotanical studies have been performed to demonstrate the ethnopharmacological importance of $P$. avium fruits and their leaves and stems in folk medicine (Table 1). The diversity of phenolic compounds in this plant, combined with other bioactive constituents, are mainly responsible for the biological activities demonstrated, which will be discussed in the following sections of this review.

Table 1. Folk medicinal uses of Prunus avium L. fruits and some of their by-products (leaves and stems).

\begin{tabular}{cc}
\hline Plant Part Used & Medicinal Uses \\
Fruits & $\begin{array}{r}\text { Urological diseases [29,30], gouty arthritis [31], expectorant [32], } \\
\text { gastrointestinal disorders [32,33], anti-hyperglycemic [6,13], sleep } \\
\text { regulation [2,34,35], obesity [13]; }\end{array}$ \\
Leaves & $\begin{array}{r}\text { Anti-hyperglycemic [7,13], antioxidant [7], hyperthension [34], } \\
\text { cardiovascular diseases [13]; }\end{array}$ \\
Stems & Urological diseases [35], anti-hyperglycemic [7], diuretic [17], antibacterial \\
& activity [36], anti-hypercholesterolaemic [37]. \\
\hline
\end{tabular}


Although cherry blossoms are not used directly in traditional medicine, they may also be of interest as a source of bioactive compounds, and their phytochemical composition deserves to be investigated.

\section{Phenolic Compounds of Sweet Cherry By-Products}

Phenolic compounds are a large and ubiquitous group of metabolites existing in plants. Nowadays, more than 8000 phenolic compounds are known, and more than half are flavonoids [8]. They are secondary metabolites of plant foods involved in plant protection against ultraviolet radiation and pathogens [38]. Furthermore, these compounds are also responsible for plant and vegetable pigmentation [39]. Detailed knowledge about the phytochemical composition of plants and fruits is indispensable for their application in the agricultural, food, and pharmaceutical industries. Phenolic compounds are structurally characterized by an aromatic ring attached to one or more hydroxyl groups, and they can be divided into two major classes: non-flavonoids (e.g., phenolic acids) and flavonoids (e.g., flavonols, flavones, flavanones, flavan-3-ols, isoflavones, and anthocyanins) (Figure 1 and Table 2) [40,41].

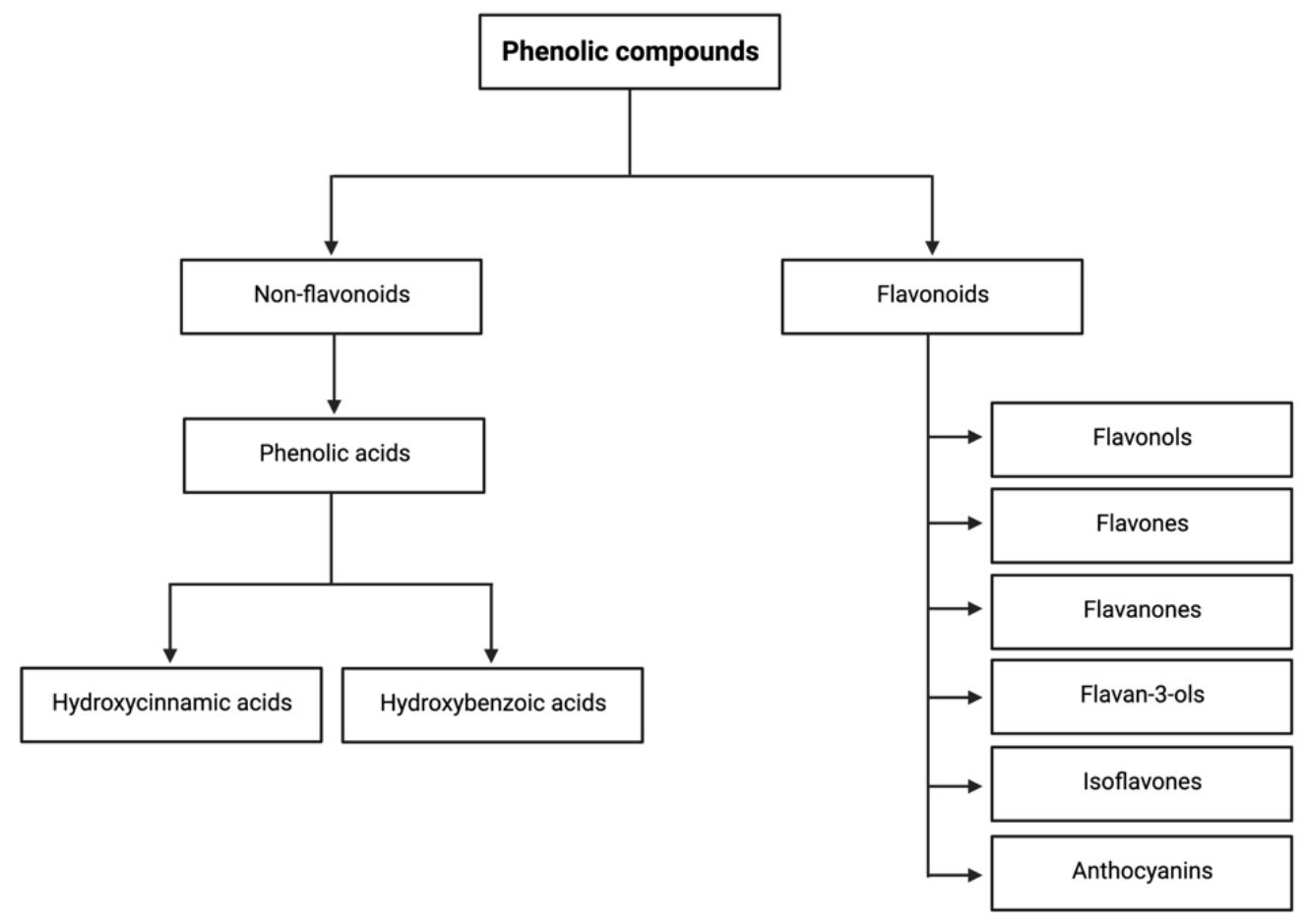

Figure 1. Chemical classification of the main phenolic compounds found in Prunus avium L.

Based mainly on high-performance liquid chromatography coupled to diode array detection and electrospray ionization/ion trap mass spectrometry (HPLC-DAD-ESI/MS ${ }^{\mathrm{n}}$ ), high-performance liquid chromatography-diode array detection (HPLC-DAD), and gas chromatography-mass spectrometry (GC-MS) separation techniques, several phenolic compounds have been identified and quantified in sweet cherry fruits and their byproducts $[5-7,10,12,18]$. It is currently well-known that these compounds are responsible for the major pharmacological and therapeutic properties found in cherries and their by-products. The phytochemical screening of $P$. avium fruits showed many phenolics such as hydroxycinnamic acids, flavan-3-ols, and anthocyanins [5,6,42]. Recently, Gonçalves et al. [18] identified 46 phenolic compounds in different sweet cherry cultivars, with contents varying from 105.6 to $5084.6 \mu \mathrm{g} / \mathrm{g}$ dry weight $(\mathrm{dw})$ for non-colored phenolics and from 4.6 to $4271.5 \mu \mathrm{g} / \mathrm{g} \mathrm{dw}$ for anthocyanins. Regarding cherry by-products, Nunes et al. [10] detected 52 phenolic compounds, with the hydroxycinnamic acids being the major ones. The total phenolics quantified in these by-products ranged between 
$12,932.15$ and $63,704.81 \mu \mathrm{g} / \mathrm{g} \mathrm{dw}$, with the hydroethanolic extract of leaves being the richest, followed by the aqueous infusion of flowers and leaves [10]. The main phenolic compounds present in P. avium by-products (stems, leaves, and flowers) and fruits are summarized in Table 3.

Table 2. Classes of phenolic compounds in the plant kingdom.

\begin{tabular}{ccc}
\hline Number of Carbon Atom & Structure & Class \\
\hline 6 & $\mathrm{C}_{6}$ & Simple phenolics \\
7 & $\mathrm{C}_{6}-\mathrm{C}_{1}$ & Benzoquinones \\
8 & $\mathrm{C}_{6}-\mathrm{C}_{2}$ & Hydroxybenzoic acids \\
& & Acetophenones \\
9 & $\mathrm{C}_{6}-\mathrm{C}_{3}$ & Phenylacetic acids \\
10 & $\mathrm{C}_{6}-\mathrm{C}_{4}$ & Hydroxycinnamic acids \\
13 & $\mathrm{C}_{6}-\mathrm{C}_{1}-\mathrm{C}_{6}$ & Coumarins \\
14 & $\mathrm{C}_{6}-\mathrm{C}_{2}-\mathrm{C}_{6}$ & Naphthoquinones \\
15 & $\mathrm{C}_{6}-\mathrm{C}_{3}-\mathrm{C}_{6}$ & Xanthones \\
18 & $\left(\mathrm{C}_{6}-\mathrm{C}_{3}\right)_{2}$ & Stilbenes \\
30 & $\left(\mathrm{C}_{6}-\mathrm{C}_{3}-\mathrm{C}_{6}\right)_{2}$ & Flavonoids \\
$\mathrm{N}$ & $\left(\mathrm{C}_{6}-\mathrm{C}_{3}-\mathrm{C}_{6}\right)_{\mathrm{n}}$ & Isoflavonoids \\
& & Lignans \\
& & Bioflavonoids \\
\hline
\end{tabular}

Table 3. Main phenolic compounds detected and quantified in P. avium L. fruits and their by-products.

\begin{tabular}{|c|c|c|c|}
\hline Phenolic Compound & Prunus avium L. Part & Content $(\mu \mathrm{g} / \mathrm{g} \mathrm{dw})$ & References \\
\hline \multicolumn{4}{|c|}{ Hydroxybenzoic Acids } \\
\hline \multirow{2}{*}{ Hydroxybenzoic acid derivative } & Fruits & $33.26-1839.54$ & {$[5,6]$} \\
\hline & Stems & $299.3-918.4$ & [7] \\
\hline Protocatechuic acid derivative & Fruits & $33.3-1539.0$ & [18] \\
\hline Protocatechuic acid-glycoside & Fruits & $5.9-476.2$ & {$[18]$} \\
\hline \multicolumn{4}{|c|}{ Hydroxycinnamic Acids } \\
\hline \multirow{3}{*}{ 3-O-Caffeoylquinic acid } & Fruit & $4.2-1733.4$ & {$[5,12,18]$} \\
\hline & Stems & $1154.9-1178.2$ & [7] \\
\hline & Leaves & $11.28-8374.8$ & [7] \\
\hline \multirow{2}{*}{ 4-Caffeoylquinic acid } & Fruit & $1.7-130.9$ & [18] \\
\hline & Leaves & $466.37-908.93$ & [10] \\
\hline 3-Coumaroyl-4-caffeoylquinic acid & Fruits & $2.0-357.1$ & [18] \\
\hline 3-Coumaroyl-5-caffeoylquinic acid & Fruits & $0.6-93.5$ & {$[18]$} \\
\hline 4-Coumaroylquinic acid & Fruit & $3.1-79.7$ & {$[18]$} \\
\hline \multirow{2}{*}{ 3,5-Dicaffeoylquinic acid } & Fruit & $0.4-29.7$ & [18] \\
\hline & Stems & 158.85 & {$[10]$} \\
\hline 4,5-Dicaffeoylquinic acid & Fruit & $5.7-44.2$ & [18] \\
\hline Caffeoyl hexose & Fruit & $3.1-271.3$ & [18] \\
\hline \multirow{2}{*}{ Caffeoylquinic acid-glycoside } & Fruit & $2.1-617.4$ & [18] \\
\hline & Stems & $1936.4-2117.33$ & {$[10]$} \\
\hline \multirow{4}{*}{ cis-3-O-Caffeoylquinic acid } & Fruit & $19.08-2342.8$ & [18] \\
\hline & Stems & $196.23-320.23$ & {$[10]$} \\
\hline & Leaves & $18,667.85-20,215.87$ & [10] \\
\hline & Flowers & $15,996.99-23,294.66$ & [10] \\
\hline cis-3-Coumaroylquinic acid & Fruit & $0.8-191.1$ & {$[18]$} \\
\hline Coumaroyl hexose derivative & Fruit & $6.9-143.2$ & [18] \\
\hline
\end{tabular}


Table 3. Cont.

\begin{tabular}{|c|c|c|c|}
\hline Phenolic Compound & Prunus avium L. Part & Content $(\mu \mathrm{g} / \mathrm{g} \mathrm{dw})$ & References \\
\hline Dicaffeoylquinic acid & Leaves & $2210.36-3375.96$ & [10] \\
\hline Ferulic acid hexoside & Stems & $170-300$ & [12] \\
\hline Feruloyl di-hexose & Fruit & $0.9-82.0$ & [18] \\
\hline Feruloyl hexose & Fruit & $3.50-475.4$ & [18] \\
\hline Feruloylquinic acid & Fruit & $3.6-3.8$ & [18] \\
\hline trans-3-Coumaroylquinic acid & Fruit & $7.0-71.6$ & {$[18]$} \\
\hline \multirow{4}{*}{ trans-5-Caffeoylquinic acid } & Fruit & $1.1-145.7$ & {$[5,18]$} \\
\hline & Leaves & $24,425.04-27,210.54$ & [10] \\
\hline & Stems & $1095.96-1338.68$ & [10] \\
\hline & Flowers & $640.77-3841.41$ & [10] \\
\hline Sinapic acid & Stems & $170-290$ & [12] \\
\hline Caffeic acid & Fruits & 11.19 & [5] \\
\hline cis $p$-coumaroylquinic acid & Fruits & 560 & [12] \\
\hline \multirow{4}{*}{ Hydroxycinnamic acid derivative } & Fruits & $33.95-86.56$ & [5] \\
\hline & Stems & $361.8-905.3$ & [7] \\
\hline & Leaves & $327.4-12,932.2$ & [7] \\
\hline & Flowers & $997.9-16,467.8$ & [7] \\
\hline$p$-Coumaric acid & Fruits & $11.32-16.91$ & {$[5]$} \\
\hline Protocatechuic acid-glycoside & Fruits & $5.9-476.2$ & [18] \\
\hline \multirow{4}{*}{$p$-Coumaric acid derivative } & Fruits & $2.35-28.49$ & [5] \\
\hline & Stems & $119.4-197.0$ & [7] \\
\hline & Leaves & $689.0-1482.13$ & {$[7,10]$} \\
\hline & Flowers & $330.6-2127.0$ & [7] \\
\hline$p$-Coumaric acid hexoside & Stems & $250-680$ & [12] \\
\hline \multirow{3}{*}{$p$-Coumaroylquinic acid } & Fruits & $4.06-28.49$ & [6] \\
\hline & Stems & $100-530$ & {$[7,12]$} \\
\hline & Leaves & 450.79-927.7 & {$[7,10]$} \\
\hline trans p-coumaroylquinic acid & Fruits & 230 & {$[12]$} \\
\hline \multicolumn{4}{|c|}{ Flavones } \\
\hline Apigenin & Stems & 32.7 & [28] \\
\hline Chrysin-7-O-glucoside & Stems & 500.0 & {$[12]$} \\
\hline \multicolumn{4}{|c|}{ Flavonols } \\
\hline Aromadendrin-7-O-hexoside & Stems & 2660 & [12] \\
\hline Aromadendrin-O-hexoside & Stems & 310 & {$[12]$} \\
\hline Isorhamnetin 3-O-rutinoside & Fruits & $5.6-29.8$ & {$[18]$} \\
\hline \multirow{3}{*}{ Kaempferol 3-O-glucoside } & Stems & $74.7-243.6$ & [7] \\
\hline & Leaves & $594.2-1467.7$ & [7] \\
\hline & Flowers & $429.4-787.3$ & [7] \\
\hline \multirow{4}{*}{ Kaempferol 3-O-rutinoside } & Fruits & $5.29-14.45$ & {$[5,18]$} \\
\hline & Stems & $161.3-417.0$ & [7] \\
\hline & Leaves & $1298.58-3125.9$ & {$[7,10]$} \\
\hline & Flowers & $468.0-671.5$ & [7] \\
\hline \multirow{2}{*}{ Kaempferol derivative } & Fruits & $155.1-349.7$ & [18] \\
\hline & Flowers & $146.6-396.9$ & {$[7]$} \\
\hline \multirow{2}{*}{ Kaempferol hexoside } & Fruits & $1.0-11.4$ & [18] \\
\hline & Leaves & 1542.19 & [10] \\
\hline
\end{tabular}


Table 3. Cont.

\begin{tabular}{|c|c|c|c|}
\hline Phenolic Compound & Prunus avium L. Part & Content $(\mu \mathrm{g} / \mathrm{g} \mathrm{dw})$ & References \\
\hline Kaempferol-O-rutinoside-O-hexoside & Flowers & $2676.77-5313.35$ & {$[10]$} \\
\hline Methyl- aromadendrin-O-hexoside & Stems & 60 & [12] \\
\hline Quercetin & Fruits & $2.32-9.22$ & [5] \\
\hline \multirow{3}{*}{ Quercetin 3-O-glucoside } & Fruits & $4.96-14.72$ & [5] \\
\hline & Stems & $61.0-140.0$ & [7] \\
\hline & Leaves & 900.4-1794.9 & [7] \\
\hline \multirow{2}{*}{ Quercetin 3-O-hexoside } & Fruits & $0.7-9.3$ & [18] \\
\hline & Flowers & $555.16-702.74$ & {$[10]$} \\
\hline \multirow{4}{*}{ Quercetin 3-O-rutinoside } & Fruits & $1.0-53.8$ & {$[5,18]$} \\
\hline & Stems & $559.1-643.3$ & [7] \\
\hline & Leaves & $3653.48-6728.0$ & {$[7,10]$} \\
\hline & Flowers & $1823.94-2547.3$ & {$[7,10]$} \\
\hline Quercetin 7-O-glucoside-3-O-rutinoside & Fruits & $0.9-46.1$ & [18] \\
\hline \multirow{4}{*}{ Quercetin derivative } & Fruits & $0.7-30.5$ & [18] \\
\hline & Stems & $255.4-313.2$ & [7] \\
\hline & Leaves & $1742.9-2537.3$ & [7] \\
\hline & Flowers & $3149.5-3701.9$ & [7] \\
\hline Quercetin $O$-rutinoside-O-hexoside & Fruits & 420 & {$[12]$} \\
\hline Taxifolin-7-O-hexoside & Stems & 790 & [12] \\
\hline Taxifolin-O-deoxyhexosylhexoside & Fruits & 660 & [12] \\
\hline Taxifolin-O-hexoside & Fruits & 130 & [12] \\
\hline \multicolumn{4}{|c|}{ Flavanones } \\
\hline Naringenin 7-O-glucoside & Stems & $2836.4-4036.2$ & [7] \\
\hline Naringenin 7-O-hexoside & Stems & 1482.67-1940.77 & [10] \\
\hline Naringenin-O-hexoside & Fruits & $38.1-170$ & {$[12,18]$} \\
\hline \multirow{3}{*}{ Sakuranetin } & Stems & $50.7-5700.9$ & [7] \\
\hline & Leaves & 1005.3 & [7] \\
\hline & Flowers & 3065.9 & [7] \\
\hline \multirow{2}{*}{ Sakuranetin 5-O-glucoside } & Fruits & 620 & [12] \\
\hline & Stems & 3630 & [12] \\
\hline Sakuranetin 5-O-hexoside & Leaves & $214.66-265.89$ & [10] \\
\hline \multirow{2}{*}{ Sakuranetin derivative } & Leaves & 196.5-2077.3 & [7] \\
\hline & Stems & $11,555.9-13,500.3$ & [7] \\
\hline Sakuranetin-O-pentosylhexoside & Stems & 360 & [12] \\
\hline Pinocembrin-O-pentosylhexoside & Stems & 230 & [12] \\
\hline \multirow{3}{*}{ Genistein } & Isoflavones & & \\
\hline & Leaves & 7324.5 & [7] \\
\hline & Stems & 697.1 & [7] \\
\hline Genistein derivative & Stems & 1044.8 & [7] \\
\hline Genistein-7-O-glucoside & Stems & 182.0 & [12] \\
\hline \multirow{3}{*}{ Catechin } & Flavan-3-ols & & \\
\hline & Fruits & 22.4 & [18] \\
\hline & Stems & $5014.0-5259.5$ & {$[7]$} \\
\hline Catechin hexoside & Fruits & 1680 & [12] \\
\hline Procyanidin dimer B type 1 & Fruits & $6.2-290.6$ & [18] \\
\hline \multirow{2}{*}{ Procyanidin dimer B type 2} & Fruits & $28.1-162.7$ & [7] \\
\hline & Stems & $7149.5-8810.67$ & [18] \\
\hline
\end{tabular}


Table 3. Cont.

\begin{tabular}{|c|c|c|c|}
\hline Phenolic Compound & Prunus avium L. Part & Content $(\mu \mathrm{g} / \mathrm{g} \mathrm{dw})$ & References \\
\hline Procyanidin dimer B type 3 & Fruits & $15.0-18.0$ & [18] \\
\hline \multicolumn{4}{|c|}{ Anthocyanins } \\
\hline Cyanidin 3-O-rutinoside & Fruits & $3.6-40,139.2$ & {$[5,18,23,43,44]$} \\
\hline Cyanidin 3-O-glucoside & Fruits & 2.19-7030 & {$[5,23,43,44]$} \\
\hline Delphinidin 3-O-rutinoside & Fruits & $2.1-204.8$ & [18] \\
\hline Pelargonidin 3-O-rutinoside & Fruits & $0.9-322.3$ & {$[5,18,23,43,44]$} \\
\hline Peonidin 3-O-glucoside & Fruits & $0.1-53.0$ & [23] \\
\hline Peonidin 3-O-rutinoside & Fruits & $0.1-59.9$ & {$[5,18,23,43,44]$} \\
\hline
\end{tabular}

\subsection{Non-Flavonoids}

Phenolic Acids

Phenolic acids are abundant in red fruits and belong to a non-flavonoid group [42,45]. They can be divided into hydroxybenzoic $\left(C_{6}-C_{1}\right)$ and hydroxycinnamic $\left(C_{6}-C_{3}\right)$ acids (Figure 2) [1,42]. Hydroxybenzoic acids are aromatic compounds composed of simple phenols, including gallic, p-hydroxybenzoic, protocatechuic, vanillic, and syringic acids. In plants, hydroxybenzoics occur mostly in the glycoside form [1]. On the other hand, hydroxycinnamic acids are phenolic acids with a three-carbon side chain. Chlorogenic, caffeic, ferulic, p-coumaric, and sinapic acids are examples of hydroxycinnamics [1].<smiles>[R6]c1cc(C(=O)O)cc([R6])c1O</smiles>

Hydroxybenzoic acids<smiles>[R]c1cc(/C=C/C(=O)O)cc([R20])c1O</smiles>

Phenolic Acids

\begin{tabular}{ccc}
\hline \multirow{2}{*}{ Acid } & \multicolumn{2}{c}{ Substitutions } \\
\cline { 2 - 3 } & $\mathbf{R}_{\mathbf{1}}$ & $\mathbf{R}_{\mathbf{2}}$ \\
\hline p-Hydroxybenzoic & $\mathrm{H}$ & $\mathrm{H}$ \\
Protocatechuic & $\mathrm{H}$ & $\mathrm{OH}$ \\
Syringic & $\mathrm{CH}_{3} \mathrm{O}$ & $\mathrm{CH}_{3} \mathrm{O}$ \\
Vanillic & $\mathrm{CH}_{3} \mathrm{O}$ & $\mathrm{H}$ \\
Gallic & $\mathrm{OH}$ & $\mathrm{OH}$ \\
\hline
\end{tabular}

\begin{tabular}{ccc}
\hline \multirow{2}{*}{ Acid } & \multicolumn{2}{c}{ Substitutions } \\
\cline { 2 - 3 } & $\mathbf{R}_{\mathbf{1}}$ & $\mathbf{R}_{\mathbf{2}}$ \\
\hline p-coumaric & $\mathrm{H}$ & $\mathrm{H}$ \\
Caffeic & $\mathrm{H}$ & $\mathrm{OH}$ \\
Ferulic & $\mathrm{CH}_{3} \mathrm{O}$ & $\mathrm{H}$ \\
Sinapic & $\mathrm{CH}_{3} \mathrm{O}$ & $\mathrm{CH}_{3} \mathrm{O}$ \\
\hline
\end{tabular}

Figure 2. Chemical structure of main phenolic acids (hydroxybenzoic and hydroxycinnamic acids) found in Prunus avium L.

Both the by-products and fruits of P. avium contain a minor amount of hydroxybenzoic acids. In by-products, the hydroxybenzoic acid derivative and protocatechuic acid aglycone were the only hydroxybenzoics detected $[7,10]$. In the hydroethanolic extract and the aqueous infusion of cherry stems, the hydroxybenzoic acid derivative content was $299.3 \pm 6.4$ and $918.4 \pm 31.2 \mu \mathrm{g} / \mathrm{g} \mathrm{dw}$, respectively [7] (Table 3). There are no reports about the presence of this type of phenolic acid in cherry leaves and flowers.

Regarding the sweet cherry fruit, two hydroxybenzoics have been reported, such as a protocatechuic acid derivative and a protocatechuic acid-glycoside [18]. The first compound was identified for the first time in this study and presented higher amounts 
$(1538.92 \mu \mathrm{g} / \mathrm{g} \mathrm{dw})$ in the Satin cultivar of P. avium [18] (Table 3). The same research team obtained similar results in previous work with Portuguese sweet cherries [6]. Other hydroxybenzoic acids such as gallic, p-hydroxybenzoic, and 2,5-dihydroxybenzoic acids have also been found in cherries [1].

Hydroxycinnamic acids are products of the phenylpropanoid pathway possessing the basic structure of trans-phenyl-3-propenoic acid, with one or more hydroxyl groups attached to the phenyl moiety. They may have a trans or cis configuration and are ubiquitous in the plant kingdom. Many studies have reported that hydroxycinnamics are the class of phenolics present in significant amounts in cherries and their by-products $[7,12,18,44]$.

Phytochemical studies have showed that hydroxycinnamic acids are the main compounds present in $P$. avium by-products. A study conducted by Bastos et al. [12] found p-coumaric acid hexoside, p-coumaroylquinic acid, and 3-O-caffeyolquinic acid in hydromethanolic extracts, infusions, and decoctions of P. avium stems (Table 3). Moreover, ferulic acid hexoside and sinapic acid were also quantified in considerable amounts [12] Caffeoylquinic acid-glycoside, cis-3-O-caffeoylquinic acid, and trans-5-caffeyolquinic acid were other hydroxycinnamic acids reported in cherry stems [10]. Similarly, other studies quantified hydroxycinnamic acids at a total of 3506.9 and $3484.0 \mu \mathrm{g} / \mathrm{g} \mathrm{dw}$ in hydroethanolic extracts and aqueous infusions of stems, respectively [7]. These values correspond to ca. $9.4 \%$ and $13.2 \%$ of total phenolic compounds [7].

Regarding P. avium leaves, this type of phenolic acid is present at a total of $34,858.1$ and $43,882.7 \mu \mathrm{g} / \mathrm{g} \mathrm{dw}$, representing $75.3 \%$ and $63.7 \%$ of total phenolics quantified in the aqueous infusion and hydroethanolic extract, respectively [7]. Data from the literature show that 5-O-caffeoylquinic acid was the major compound found in extracts of cherry leaves, followed by 3-O-caffeoylquinic acid [7,10]. Hydroxycinnamic acid derivatives, p-coumaric, dicaffeoylquinic, and p-coumaroylquinic acids were also detected in P. avium leaves (Table 3) [7,10]. Dziadek et al. [13] reported the presence of caffeic, chlorogenic, and p-coumaric acids in cherry leaves at higher amounts than those found in fruits. Moreover, ferulic acid was identified for the first time in this study, while chlorogenic acid was the predominant hydroxycinnamic acid found just in cherry [13].

In P. avium flowers, Jesus et al. [7] found the total hydroxycinnamic content to be between $17,387.7$ and $23,249.4 \mu \mathrm{g} / \mathrm{g} \mathrm{dw}$ in studied extracts. The main phenolic acids identified in cherry flowers were hydroxycinnamic acid derivatives, cis-3-caffeoylquinic acid, and 5-O-caffeoylquinic acid (Table 3) [7,10]. The hydroxycinnamic acids reported in P. avium flowers correspond to about $49.8 \%$ and $67 \%$ of total phenolics, with hydroxycinnamic acid derivatives and 3 and 5-O-caffeoylquinic acids being the majority compounds $[7,10]$.

With regard to the cherry fruit, its hydroxycinnamic composition has also been evaluated and reported in some studies [18,44]. In a study conducted by Martini et al. [44], the total content of hydroxycinnamic acids ranged between $39.75 \%$ and $57.67 \%$ in six different cultivars of sweet cherry. Cis-3-Coumaroylquinic acid, trans-3-coumaroylquinic acid, cis-3-caffeoylquinic acid, trans-3-caffeoylquinic acid, and trans-5-caffeoylquinic acid were the main phenolic acids found in this study, representing an average of $42.85 \%$ of total phenolic compounds [44]. In another study, Gonçalves et al. [18] identified nineteen hydroxycinnamic acids in P. avium fruit extracts, with chlorogenic acids being the most predominant, comprising $66.16 \%$ of total non-colored phenolics and $37.13 \%$ of total phenolics, followed by caffeoylquinic acids ranging from $32.6 \%$ to $57.7 \%$ of total phenolics. Caffeoylquinic acid glycosides, p-coumaric acids, and ferulic acids were other phenolic acids identified in this work, but found in minor amounts [18].

In $P$. avium by-products and cherry fruit, the hydroxycinnamics were the main class of phenolic acids present $[5-7,10,12,18]$. 


\subsection{Flavonoids}

Flavonoids are the main class of phenolic compounds found in plants that have been extensively studied [46]. These compounds possess fifteen carbon atoms arranged in a $\mathrm{C}_{6}-\mathrm{C}_{3}-\mathrm{C}_{6}$ configuration [47]. Flavonoids are composed of two phenolic rings (A and B) linked by a 3-carbon chain that forms a pyran ring (heterocyclic ring containing oxygen, C-ring). The aromatic A-ring derives from the acetate pathway, whereas the shikimate pathway generates the $\mathrm{B}$ and $\mathrm{C}$-rings. Their structural variability is due to the variation in the number and arrangement of hydroxyl groups and the degree of alkylation, methylation, and glycosylation. As previously mentioned, they can be divided into six subclasses: flavonols, flavones, flavanones, isoflavones, flavan-3-ols, and anthocyanins [48] (Figure 3). Typically, flavonoids are found in nature with a sugar molecule, O-glycosides, bound to the hydroxyl group at the $\mathrm{C}_{3}$ or $\mathrm{C}_{7}$ position. Additionally, flavan-3-ols are the only subclass of flavonoids found in plants as aglycones (without sugar moieties) [49].

\section{Flavonoids}

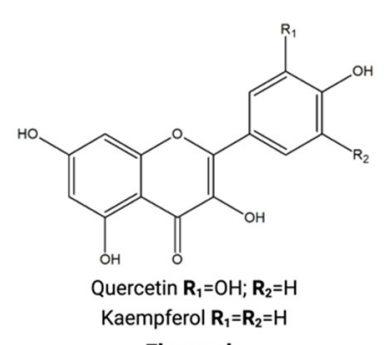

Flavonols<smiles>[R]c1cccc([C@H]2Oc3cc(O)cc(O)c3C[C@H](O)[C@H]2c2cc([R])c(O)c([R])c2)c1</smiles>

Flavan-3-ols
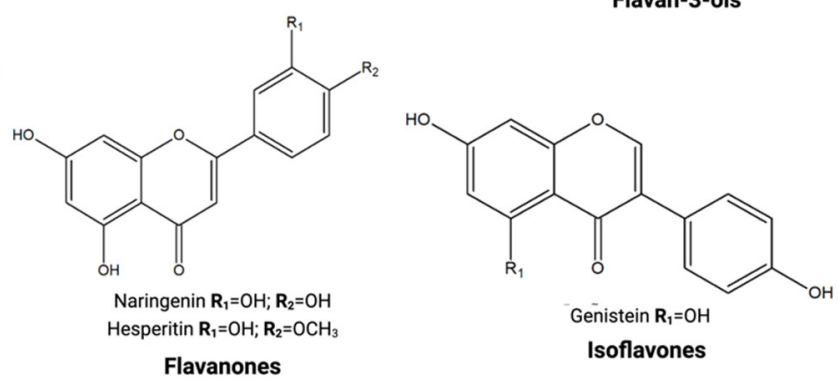

Figure 3. Chemical structure of the main subclasses of flavonoids found in Prunus avium L. byproducts.

Flavonoid hydroxyl groups close to conjugated electron- $\pi$ systems quickly supply hydrogen to reactive oxygen species (ROS) and reactive nitrogen species (RNS), thereby neutralizing them $[50,51]$. This action mechanism happens because these phytochemicals can be absorbed by and retained in cells. However, its efficiency is specific to each cell type, given that intracellular metabolism and export rates vary between cells [52].

\subsubsection{Flavones}

Flavones are present in most vegetables but in lower amounts, contributing to the yellow pigmentation of plant tissues and food taste. Its chemical structure is similar to that of flavonols, having an unsaturation at the $C_{2}-C_{3}$ position of the heterocyclic ring $C$, given the absence of a hydroxyl group at position 3 of the same ring [53]. Apigenin, luteolin, and diosmetin are the most common flavones found in nature, and they occur more frequently as 3-glycosides [54]. Additionally, they can form glycosidic bonds, promoting intestinal absorption in the human body $[53,55]$.

The presence of flavones in P. avium by-products and fruits is poorly known $[1,10]$. According to the literature data, their presence has only been described in the sweet cherry stems [12,28]. Chrysin 7-O-hexoside has been identified in P. avium stems (Table 3) [10,12]. In another study, Aires et al. [28] reported the presence of apigenin $(32.7 \pm 0.1 \mu \mathrm{g} / \mathrm{g} \mathrm{dw})$ in 
stems (Table 3). There are no reports about the existence of flavones in leaves, flowers, and fruits of $P$. avium.

\subsubsection{Flavonols}

Flavonols are very common in the human diet, especially in fruits, vegetables, and tea. Their chemical structure is similar to that of flavones, having a 3-hydroxy pyran-4one group on the C-ring and a 2,3-double bond. Quercetin, kaempferol, myricetin, and isorhamnetin are the compounds most found in fruits and vegetables [23,24]. Many studies have showed that sweet cherry by-products contain several flavonols $[7,10,12,28]$.

Kaempferol 3-O-rutinoside, kaempferol 3-O-glucoside, kaempferol $O$-rutinoside- $O$ hexoside, quercetin derivative, quercetin 3-O-rutinoside, quercetin 3-O-hexoside, quercetin 3-O-glucoside, quercetin 3-O-galactoside, quercetin $\mathrm{O}$-rutinoside- $\mathrm{O}$-hexoside, and methyl quercetin $O$-rutinoside were detected in extracts of $P$. avium stems (Table 3) [10,12]. Among these flavonols, kaempferol 3-O-rutinoside, quercetin 3-O-rutinoside, and quercetin 3-Ohexoside were the compounds found in greater amounts (Table 3) $[7,10]$. Similar results were reported in sweet cherry leaves $[7,56,57]$, with contents ranging from $6728.0 \pm 328.8$ to $594.2 \pm 76 \mu \mathrm{g} / \mathrm{g} \mathrm{dw}$ (Table 3) [7]. According to Nunes et al. [10], the aqueous infusion of $P$. avium leaves is rich in quercetin $3-O$-rutinoside, comprising about $17.08 \%$ of total phenolic compounds.

P. avium flowers possess the same flavonols described in stems and leaves, with quercetin 3-O-rutinoside and kaempferol $O$-rutinoside- $O$-hexoside being the major compounds identified, which represent about $6-15 \%$ of total phenolics in cherry flower extracts $[7,10]$.

When compared with $P$. avium fruits, the major flavonol glycosides found in the fruits of four different cultivars were quercetin 3-O-rutinoside, quercetin 3-O-glucoside, kaempferol 3-O-rutinoside, and isorhamnetin 3-O-rutinoside [58]. The amount of these compounds varied between 11.4 and $46.9 \mu \mathrm{g} / \mathrm{g}$ fresh weight ( $\mathrm{fw}$ ) for quercetin 3-O-rutinoside, 1.6 and $7.9 \mu \mathrm{g} / \mathrm{g} \mathrm{fw}$ for quercetin 3-O-glucoside, 3.0 and $13.9 \mu \mathrm{g} / \mathrm{g}$ fw for kaempferol 3-O-rutinoside, and 0.8 and $1.3 \mu \mathrm{g} / \mathrm{g} \mathrm{fw}$ for isorhamnetin 3-O-rutinoside [58]. In another study, Bastos et al. [12] described the presence of quercetin-O-rutinoside-O-hexoside $(420 \pm 10 \mu \mathrm{g} / \mathrm{g} \mathrm{fw})$ in sweet cherry fruits. Similar results were recently obtained by Gonçalves et al. [18], which found thirteen flavonols in sweet cherry fruits: four quercetins, eight kaempferol derivatives, and one isorhamnetin 3-O-rutinoside, comprising about $2.04 \%$ of total non-colored phenolic compounds. The authors reported the kaempferol derivatives 1-3 and kaempferol hexoside derivatives 1 and 2 in this study for the first time [18].

\subsubsection{Flavanones}

Flavanones, also called dihydroflavones, are usually found in citrus fruits, but are also present in cherries [1]. These compounds are characterized by the presence of a chiral center at position 2, and although they are similar to flavones, they do not possess the 2,3-double-bound at $C_{3}$ [59]. Generally, flavanones are glycosylated at position 7 . The most common forms present in nature are naringenin, hesperidin, naringenin 7-O-rutinoside, and hesperetin [49].

P. avium stems were found to contain sakuranetin 5-O-glucoside, followed by naringenin 7-O-glucoside, and aromandendrin 7-O-hexoside as the major flavanones [12]. Posteriorly, other works confirm these results, showing sakuranetin and naringenin 7-Oglucoside as some of the main flavanones found in sweet cherry stem extracts (Table 3), comprising about $12 \%$ of the total phenolics $[7,10]$. Sakuranetin O-pentosyl-hexoside and pinocembrin were also reported in P. avium stems $[10,12]$.

Regarding leaves of sweet cherry sakuranetin and its derivative, sakuranetin 5-Ohexoside and naringenin hexoside were the flavanones detected $[7,10]$. Sakuranetin was found in considerable amounts in the aqueous infusion of P. avium flowers [7]. 
In the literature, there is little information about the presence of flavanones in cherry fruits. Recently, two naringenin hexosides were found in sweet cherries, but in small amounts [18]. This finding was similar to previous work, demonstrating that these compounds represent less than $1 \%$ of the total phenolic compounds $[18,44]$.

\subsubsection{Isoflavones}

Isoflavones are flavonoids with a similar structure to estrogen, and hence, they are commonly classified as phytoestrogens due to their capacity to bind to estrogen receptors. Consequently, it is not surprising that they also have pseudo-hormonal properties [60]. Unlike other flavonoids, isoflavones possess the phenylchroman B ring linked at position 3 instead of position 2; this characteristic is due to the presence of two enzymes, which are the 2'-hydroxy-isoflavone synthase and a polyketide synthase (i.e., the chalcone synthase) [55]. The main sources of isoflavones are soy and its processed products, namely genistein, daidzein, and glycitein [61].

Genistein, genistein derivatives, and the genistein-7-O-glucoside have been reported in cherry stems [7]. Genistein has been found in leaves [12]. To our knowledge, there are no studies that report the existence of isoflavones in P. avium fruits and flowers.

\subsubsection{Flavan-3-ols}

Flavan-3-ols can be found in many plant foods and supplements such as cacao, red wine, tea, and fruits, including cherries and other berries [62]. These phenolics have a non-planar structure and a hydroxyl group in $\mathrm{C}_{3}$ of the $\mathrm{C}$-ring and are characterized by the absence of the pyran-4-one structure and the lack of the 2,3-double bond in the C-ring [19]. These flavonoids can range from simple monomers (e.g., catechins) to oligomeric and polymeric forms (e.g., condensed tannins) [19]. Additionally, they do not show a moiety residue in foods.

Condensed tannins are usually present in foods in connection with catechins. They are responsible for giving flavor and astringent character to certain foods and beverages due to the formation of complexes with salivary proteins [19]. Moreover, there are other classes of condensed tannins such as hydrolyzable and complex tannins [63]. These compounds have a polyol (generally D-glucose) as a central core, and the hydroxyl groups are partially or totally esterified with phenolic acids such as gallic acid (gallotannins) or ellagic acid (ellagitannins). Mild acids and bases easily hydrolyze this type of tannins, originating sugars and phenolic acids [19]. In the literature, it has been reported that flavan-3-ol levels are significantly influenced by genotype and environmental and agronomical conditions [64], which explains the significant differences obtained by different authors [7,12,18].

Concerning $P$. avium by-products, different authors have reported the presence of flavan-3-ols in cherry stems $[7,10,12,28]$. Aires et al. [28] described the presence of catechin $(159.1 \pm 0.4 \mu \mathrm{g} / \mathrm{g} \mathrm{dw})$ and epicatechin $(87.3 \pm 0.2 \mu \mathrm{g} / \mathrm{g} \mathrm{dw})$ (Table 3), corresponding to $12.5 \%$ of the total polyphenols identified in stems (Table 3). More recently, Jesus et al. [7] described the epigallocatechin $(950.6 \pm 59.8$ and $951.2 \pm 57.2 \mu \mathrm{g} / \mathrm{g} \mathrm{dw}$ ) and catechin derivatives $(197.0 \pm 4.0$ and $179.3 \pm 20.0 \mu \mathrm{g} / \mathrm{g} \mathrm{dw})$ in both the hydroethanolic extract and infusion, respectively (Table 3). Procyanidin dimer B type 2 was another flavan-3-ol found in cherry stems, corresponding to about $55 \%$ of the phenolic compounds quantified in stem extracts (Table 3) [10].

For the first time, catechin hexoside was found in P. avium leaves by Nunes et al. [10]. With respect to the flowers of $P$. avium, there are no reports about the presence of these phenolics.

These compounds in P. avium fruits represent less than $11.29 \%$ of the total non-colored compounds (ca. $4.48 \mu \mathrm{g} / \mathrm{g} \mathrm{dw}$ ) [18]. According to Gonçalves et al. [18], catechins and procyanidins were the flavan-3-ols found in sweet cherry fruits. Their presence has already been reported in other studies $[6,11,55]$. Furthermore, procyanidins were identified in sweet cherry fruits from different cultivars (values ranging from 6.2 to $290.6 \mu \mathrm{g} / \mathrm{g} \mathrm{dw}$ ), representing less than $18 \%$ of the total non-colored phenolics [18]. 


\subsubsection{Anthocyanins}

Anthocyanins are widespread throughout nature, being the essential pigments in plants and natural foods. Furthermore, fruits and their juices, flowers, wine, and cereals possess high anthocyanins levels [19], with their content being proportional to their color intensity [65]. Structurally, they present the basic three-ring skeleton of flavonoids, with an oxonium ion on their C-ring. The existence of several hydroxyl groups provides the anthocyanins with remarkable antioxidant effects $[6,66]$. Cyanidin, delphinidin, malvidin, pelargonidin, peonidin, and petunidin are the main anthocyanins found in fruits and vegetables [67]. These compounds are colored and exist in considerable amounts in cherries (Table 3).

The analysis of twenty-four sweet cherry cultivars indicates that the total anthocyanin content ranged from 6.21 to $94.20 \mathrm{mg}$ cyanidin 3-glucoside equivalents $/ 100 \mathrm{~g} \mathrm{fw}$; nonetheless, variations occurred among the different cultivars [68]. In another study, the percentage of anthocyanins in the six sweet cherry cultivars ranged from 0.58 to $37.57 \%$ [33]. Recently, Gonçalves et al. [18] showed that different cultivars from the Fundão region (Portugal) possess higher total anthocyanin content $(3267.5-4271.5 \mu \mathrm{g} / \mathrm{g} \mathrm{dw})$. According to the literature, cyanidin 3-O-rutinoside is the main one $(3.6-40,139.2 \mu \mathrm{g} / \mathrm{g} \mathrm{dw})$, followed by cyanidin 3-O-glucoside (2.19-164.60 $\mathrm{\mu g} / \mathrm{g} \mathrm{dw})$, pelargonidin 3-O-rutinoside (0.9-322.3 $\mu \mathrm{g} / \mathrm{g} \mathrm{dw})$, delphinidin 3-O-rutinoside (2.1-204.8 $\mu \mathrm{g} / \mathrm{g} \mathrm{dw})$, and peonidin 3-Orutinoside $(0.1-59.9 \mu \mathrm{g} / \mathrm{g} \mathrm{dw})[5,18,23,44]$. Cyanidin 3-O-rutinose comprises about $90 \%$ and $70 \%$ of total anthocyanins and phenolic compounds, respectively $[18,68]$. As far as we know, there are no reports about the occurrence of anthocyanins in cherry by-products.

\section{Biological Properties of Prunus avium L. By-Products}

The biological properties of P. avium stems, leaves, and flowers have been attributed to their phytochemical composition, mostly to their content in phenolic compounds. Several studies on extracts and aqueous infusions from cherry by-products have described many bioactivities such as antioxidant and anti-hyperglycemic activities $[1,9,69]$. This section will summarize the reports about the therapeutic potential of $P$. avium by-products in relation to antioxidant and anti-hyperglycemic activities.

\subsection{Antioxidant Activity}

The interest in phenolic compounds as a source of natural antioxidants has been increasing in the last years due to its beneficial effects in preventing the progression of many diseases such as DM [19]. Oxidative stress plays a crucial role in the development of this disease once the hyperglycemic state is associated with an overproduction of ROS such as hydroxyl radicals $\left({ }^{\bullet} \mathrm{OH}\right)$, hydrogen peroxide $\left(\mathrm{H}_{2} \mathrm{O}_{2}\right)$, superoxide ion $\left(\mathrm{O}_{2}{ }^{-}\right)$, and RNS as nitric oxide radical $\left({ }^{\bullet} \mathrm{NO}\right)[70,71]$. These radicals are responsible for inducing lipidic peroxidation, resulting in the damage of lipids, lipoproteins, and membranes, and causing DNA mutations [71], which can lead to the development of other diseases such as multiple sclerosis and cancer [72]. Bioactive compounds present in P. avium by-products possess high antioxidant potential towards free radicals, which has been evaluated through different in vitro assays that include free radical scavenging ability, the chelation of metal ions, and the inhibition of lipid peroxidation [7,12,13,73,74].

Several researchers have evaluated the antioxidant potential of extracts or the main isolated compounds from P. avium L. by-products. Table 4 summarizes the results of main studies that revealed evidence for the potent antioxidant activity of cherry stems, leaves, and flowers. In a study conducted by Prvulovic et al. [74], the antioxidant activity of seventeen different cultivars of $P$. avium stems was evaluated, measuring the scavenging activity on the 2,2-diphenyl-1-picrylhydrazyl (DPPH) radicals. The obtained results showed that significant differences exist in the phenolic content of different genotypes, and consequently, differences in the scavenging activity of DPPH-radicals [74]. The extracts from all cultivars showed high antioxidant potential, with DPPH-values ranging from $29.88 \%$ to $86.94 \%$. As expected, the genotypes with the highest amounts in phenolic compounds showed the 
highest DPPH-radical scavenging activity [74], demonstrating the relationship between phenolic content and antioxidant activity. In another study developed by Bastos et al. [12], the antioxidant activity of the hydromethanolic extract, infusion, and decoction of P. avium stems were screened by four different methods: DPPH free radical scavenging, ferric reducing antioxidant power (FRAP) assay, system $\beta$-carotene/linoleic acid assay, and thiobarbituric acid-reactive substances (TBARS) assay. In this study, all the preparations of cherry stems presented strong antioxidant potential, with particular emphasis on the hydromethanolic extract. The $\mathrm{EC}_{50}$ values of the studied preparations ranged from 0.36 to $0.63 \mathrm{mg} / \mathrm{mL}$ for DPPH, 0.18 to $0.44 \mathrm{mg} / \mathrm{mL}$ for FRAP, 0.30 to $0.42 \mathrm{mg} / \mathrm{mL}$ for lipid peroxidation, and 0.07 to $0.24 \mathrm{mg} / \mathrm{mL}$ for TBARS [12]. In the same study, P. avium stems revealed the highest antioxidant potential when compared to sweet cherry fruit extracts, probably due to a higher amount of phenolic acids and flavonoids found in this by-product [12]. According to the literature, hydroxycinnamic acids and total flavonoids correspond to about $9.4 \%$ and $89.8 \%$ of total phenolic compounds contained in the hydroethanolic extract of $P$. avium stems, with 3-O-caffeoylquinic acid being the main one $[7,12]$.

Table 4. Antioxidant activity of Prunus avium L. by-products.

\begin{tabular}{|c|c|c|c|c|}
\hline Part of Plant & Extract & Type of Study & Main Outcomes & References \\
\hline Stems & Aqueous acetone $70 \%$ & $\begin{array}{l}\text { DPPH free radical } \\
\text { scavenging activity }\end{array}$ & $\begin{array}{l}\text { Genotypes with highest phenolic } \\
\text { content possess higher DPPH } \\
\text { scavenging activity. }\end{array}$ & [74] \\
\hline Stems & $\begin{array}{l}\text { Hydroxymethanolic 80:20 } \\
(v / v) \\
\text { Aqueous infusion } \\
\text { Decoction }\end{array}$ & $\begin{array}{l}\text { DPPH free radical } \\
\text { scavenging activity } \\
\text { Reducing power by FRAP } \\
\text { method } \\
\text { Inhibition of } \beta \text {-carotene } \\
\text { bleaching } \\
\text { Thiobarbituric acid test }\end{array}$ & $\begin{array}{l}\text { All preparations revealed a strong } \\
\text { antioxidant activity, but the } \\
\text { hydromethanolic extract was the } \\
\text { most relevant; } \\
\text { The antioxidant potential is probably } \\
\text { correlated with phenolic content. }\end{array}$ & [12] \\
\hline
\end{tabular}

Hydroethanolic extracts of cherry stems and leaves were the most active against DPPH and superoxide

DPPH free radical scavenging activity

Stems

Leaves

Flowers

Ethanol/Water 1:1 (v/v)

Aqueous Infusion
Nitric oxide assay

Superoxide radical assay

In vitro $\mathrm{RO}^{\bullet}$-induced

oxidative damage in human erythrocytes radicals.

Aqueous infusion of stems showed

high antioxidant activity against nitric oxide radicals;

Hydroethanolic extract of stems was

the most active against hemolysis

and lipid peroxidation;

Flowers' hydroethanolic extracts

show good antioxidant activity

against hemoglobin oxidation.

\begin{tabular}{|c|c|c|c|c|}
\hline Stems & Methanol (70\%) & $\begin{array}{l}\text { Total antioxidant activity } \\
\text { by ABTS }{ }^{\bullet+}\end{array}$ & $\begin{array}{l}\text { Antioxidant activity is dependent on } \\
\text { extraction method. }\end{array}$ & [28] \\
\hline Stems & Methanol (70\%) & $\begin{array}{l}\text { Total antioxidant activity } \\
\text { by ABTS }{ }^{\bullet+} \\
\text { DPPH free radical } \\
\text { scavenging activity } \\
\text { Inhibition of } \beta \text {-carotene } \\
\text { bleaching } \\
\text { Reducing power by FRAP } \\
\text { method }\end{array}$ & $\begin{array}{l}\text { Positive correlation between the } \\
\text { antioxidant potential and the } \\
\text { content of phenolic compounds. }\end{array}$ & [73] \\
\hline $\begin{array}{l}\text { Leaves } \\
\text { Stems } \\
\text { Flowers }\end{array}$ & $\begin{array}{l}\text { Ethanol/Water 50:50 (v/v) } \\
\text { Aqueous Infusion }\end{array}$ & $\begin{array}{l}\text { DPPH free radical } \\
\text { scavenging activity }\end{array}$ & $\begin{array}{l}\text { Hydroethanolic extract and aqueous } \\
\text { infusion of stems showed high } \\
\text { antioxidant activity. }\end{array}$ & [10] \\
\hline
\end{tabular}


To determine the total antioxidant activity of flavonoids extracted from cherry stems through two different extraction methods (conventional and ultrasound-assisted extraction), Aires et al. [75] used the 2,2' -azino-bis-3-ethylben-zothiazoline-6-sulphonate (ABTS ${ }^{\bullet+}$ ) radical cation assay. The obtained results showed that stem extracts possess great antioxidant potential. The extraction method used affected the $\mathrm{IC}_{50}$ values of total antioxidant activity due to their yield in flavonoid extraction [75]. In this study, it was found that the antioxidant activity depends on the synergetic effects among different phenolics. Higher contents of phenolic compounds such as sakuranetin, isosakuranetin, neochlorogenic and chlorogenic acid, catechin and the epicatechin derivative, and $p$-coumaric acid and the $p$-coumaroylquinic acid derivative all lead to greater antioxidant activity.

More recently, in a study conducted by Jesus et al. [7], the antioxidant activity of hydroethanolic extracts and infusions of P. avium leaves, stems, and flowers were evaluated through DPPH free radical scavenging, and the other radicals such as $\mathrm{O}_{2}^{\bullet-}$ and ${ }^{\bullet} \mathrm{NO}$. The DPPH method showed that the hydroethanolic extract of stems was the most active $\left(\mathrm{IC}_{50}=22.37 \pm 0.29 \mu \mathrm{g} / \mathrm{mL}\right)$, while the scavenging activity of $\bullet \mathrm{NO}$ was more effective in the infusion of this by-product $\left(\mathrm{IC}_{50}=99.99 \pm 1.89 \mu \mathrm{g} / \mathrm{mL}\right)$. The evaluation against $\mathrm{O}_{2}{ }^{-}$showed that the hydroethanolic extract of leaves was noteworthy among the others $\left(\mathrm{IC}_{50}=9.11 \pm 0.16 \mu \mathrm{g} / \mathrm{mL}\right)$ [7]. In this study, a positive correlation was detected between the activity of P. avium stems against DPPH radicals and the total phenolic acids $(\mathrm{r}=0.9767)$, and also their potential against ${ }^{\circ} \mathrm{NO}$ and total phenolics and total amount of flavonoids ( $r=0.9575$ and $r=0.9537$, respectively). These results could be related to the chemical structure of identified phenolics due to their richness in hydroxyl groups $(\mathrm{OH})$. Similarly, in another study, the aqueous infusion and the hydroethanolic extract of the stems, leaves, and flowers of $P$. avium were compared according to their free radical scavenging capacity [10]. The results showed that the hydroethanolic extracts of stems exhibited the strongest antioxidant activity in the DPPH assay, followed the aqueous infusion $\left(\mathrm{IC}_{50}=19.04 \pm 0.3\right.$ and $\mathrm{IC}_{50}=28.41 \pm 0.55 \mu \mathrm{g} / \mathrm{mL}$, respectively). Moreover, after comparing the different extracts of cherry by-products, P. avium leaves showed better antioxidant activity than flowers [10].

In sum, $P$. avium by-products such as sweet cherries may be a new promising source of phenolic compounds, given that they have already been proven to possess considerable antioxidant activity.

\subsection{Anti-Hyperglycemic Activity}

$\mathrm{DM}$ is one of the main metabolic diseases with a high morbidity and mortality rate, representing a severe socioeconomic problem in developed countries [76]. It is characterized by impaired insulin action or insulin resistance, leading to chronic hyperglycemia. Moreover, it is widely accepted that oxidative stress plays an important role in this disease's pathogenesis, inducing micro- and macrovascular complications [77]. Alterations in the metabolism of carbohydrates, lipids, and proteins are the long-term complications caused by DM, resulting in the development of cardiovascular problems, obesity, and dyslipidemia.

Healthy lifestyle habits such as the practice of physical exercise and eating a balanced diet, and treatment with oral hypoglycemic drugs are the main strategies for DM prevention and control [19]. However, the pharmacological strategy has led to the appearance of adverse effects caused by allopathic drugs. Accordingly, the search for new procedures that control the early stages of hyperglycemia and/or type 2 DM (T2DM) based on safe and effective antidiabetic medicinal plants, including phenolic compounds, has been proposed [19]. The anti-hyperglycemic activity of the P. avium fruits and by-products as well as some of their main compounds were evaluated by different studies described in Table 5.

\subsubsection{In Vitro and In Vivo Studies}

Currently, one of the therapeutic strategies for controlling postprandial hyperglycemia is based on the inhibition of $\alpha$-glucosidase and $\alpha$-amylase, resulting in the delay of car- 
bohydrate digestion into absorbable monosaccharide, thus decreasing hyperglycemia levels [78]. The anti-hyperglycemic potential of P. avium by-products from the Saco cultivar of the Fundão region (Portugal) was supported by the inhibition of $\alpha$-glucosidase activity [7]. The evaluated infusions and hydroethanolic extracts of cherry leaves, stems, and flowers presented different activities in a concentration-dependent manner. The results showed that the infusion and hydroethanolic extract of stems were the most active $\left(\mathrm{IC}_{50}=3.18 \pm 0.23 \mu \mathrm{g} / \mathrm{mL}\right.$ and $7.67 \pm 0.23 \mu \mathrm{g} / \mathrm{mL}$, respectively), followed by the hydroethanolic extracts of leaves and flowers $\left(\mathrm{IC}_{50}=15.61 \pm 0.48\right.$ and $59.83 \pm 0.68 \mu \mathrm{g} / \mathrm{mL}$, respectively) [7]. In the same study, it is reported that these by-products present high phenolic acid content and have been described as $\alpha$-glucosidase and $\alpha$-amylase inhibitors [76]. Caffeic, ferulic, gallic, and protocatechuic acids are found in P. avium fruits and their by-products $[10,12,18]$. In a study developed by Ibitoye et al. [79] on high-fructose dietinduced metabolic syndrome in rats, the authors showed that these phenolic acids could decrease hyperglycemia after three weeks of treatment. Furthermore, these compounds were also responsible for restoring lipid parameters, indices of atherosclerosis indexes, and cardiovascular parameters to normal values [79]. The increase of oxidative stress was also reverted by these phenolic acids [79].

In a study developed by Gonçalves et al. [6] on sweet cherry fruits of different cultivars, the obtained results showed that all extracts of cultivars were able to inhibit $\alpha$-glucosidase in a dose-dependent manner, with $\mathrm{IC}_{50}$ values ranging from $10.25 \pm 0.49$ to $16.31 \pm 0.71 \mu \mathrm{g} / \mathrm{mL}$ [6]. Posteriorly, the same authors once again proved the inhibitory capacity of the P. avium fruit against this enzyme of the cultivar most consumed and appreciated in Portugal (i.e., Saco) [5] The verified differences among diverse cherry cultivars and their by-products may be due to each sample's phenolic composition in the study. Moreover, the authors demonstrated that the ability to inhibit this enzyme by the sweet cherry is more significant than that observed in hydroethanolic extracts of other red fruits [80,81]. Nevertheless, a direct relationship between the concentration of phenolic compounds and the anti-hyperglycemic activity was observed in the experiments [5-7].

Regarding $\alpha$-amylase, the cyanidin-3-rutinoside inhibited this enzyme, suggesting a potentially useful compound for controlling post-prandial hyperglycemia [82]. This compound is one of the main anthocyanins found in considerable amounts in sweet cherries [18]. Worthy of note is that cyanidin-3-rutinoside was also detected in P. avium leaves for the first time [10]. These results indicate the potential use of P. avium fruits and their leaves in lowering the post-prandial enhancement of blood glucose levels.

Table 5. Anti-hyperglycemic activity of Prunus avium L. fruits and by-products.

\begin{tabular}{|c|c|c|c|c|}
\hline Part of Plant/Compounds & Extract & Type of Study & Main Outcomes & References \\
\hline Stems, leaves and flowers & $\begin{array}{l}\text { Ethanol/Water 1:1 }(v / v) \\
\text { Aqueous Infusion }\end{array}$ & In vitro & $\begin{array}{l}\text { Inhibition of } \alpha \text {-glucosidase enzyme in } \\
\text { a concentration-dependent manner. }\end{array}$ & [7] \\
\hline Fruits & Ethanol 70\% & In vitro & $\begin{array}{l}\text { Inhibition of } \alpha \text {-glucosidase enzyme in } \\
\text { a concentration-dependent manner. }\end{array}$ & {$[5,6]$} \\
\hline Cyanidin-3-rutinoside & n.a. & In vitro & $\begin{array}{l}\text { Inhibition of } \alpha \text {-amilase enzyme in a } \\
\text { concentration-dependent manner. }\end{array}$ & [82] \\
\hline $\begin{array}{l}\text { Hydroxycinnamic acids, } \\
\text { flavonols, and } \\
\text { anthocyanins }\end{array}$ & $\begin{array}{l}\text { Hydroxycinnamic } \\
\text { acid-rich fraction } \\
\text { Flavonol-rich fraction } \\
\text { Anthocyanin-rich } \\
\text { fraction }\end{array}$ & In vitro & $\begin{array}{l}\text { Promotion of cellular glucose } \\
\text { consumption by HepG } 2 \text { cells. }\end{array}$ & [83] \\
\hline Kaempferol and quercetin & n.a. & In vitro & $\begin{array}{c}\uparrow \text { Insulin-stimulated glucose uptake in } \\
\text { mature 3T3-L1 adipocytes. }\end{array}$ & [84] \\
\hline
\end{tabular}


Table 5. Cont

\begin{tabular}{|c|c|c|c|c|}
\hline Part of Plant/Compounds & Extract & Type of Study & Main Outcomes & References \\
\hline $\begin{array}{c}\text { Rutin, quercetin, } \\
\text { kaempferol, genistein }\end{array}$ & n.a. & In vitro & $\begin{array}{l}\text { Improved basal glucose uptake in } \\
\text { HepG2 cells. }\end{array}$ & [85] \\
\hline Fruits & $\begin{array}{l}\text { Ingestion of } 200 \mathrm{mg} / \mathrm{kg} \\
\text { body weight of cherries }\end{array}$ & In vivo & $\begin{array}{c}\downarrow \text { Blood glucose; } \\
\downarrow \text { Urinary microalbumin; } \\
\uparrow \text { Creatinine excretion level in urea. }\end{array}$ & [86] \\
\hline $\begin{array}{l}\text { Caffeic, ferulic, gallic, and } \\
\text { protocatechuic acids }\end{array}$ & $\begin{array}{l}\text { Gavaged ( } 40 \mathrm{mg} / \mathrm{kg} \\
\text { body weight) }\end{array}$ & In vivo & $\begin{array}{l}\downarrow \text { Hyperglycemia; } \\
\downarrow \text { Insulin resistance; } \\
\downarrow \text { Dyslipidemia; } \\
\downarrow \text { Oxidative stress. }\end{array}$ & [79] \\
\hline Fruit & $\begin{array}{l}\text { Anthocyanin-depleted } \\
\text { cherry powder }\end{array}$ & In vivo & $\begin{array}{c}\text { Protective effects in the liver; } \\
\text { Prevent hepatic inflammation in } \\
\text { diabetic conditions; } \\
\downarrow \text { Fasting glucose levels. }\end{array}$ & [87] \\
\hline Caffeic acid & $\begin{array}{l}0.5-3 \mathrm{mg} / \mathrm{kg} \text { body } \\
\text { weight }\end{array}$ & In vivo & $\begin{array}{c}\downarrow \text { Plasma glucose level in } \\
\text { insulin-resistant rats; } \\
\uparrow \text { Glucose uptake into the isolated } \\
\text { adipocytes in a } \\
\text { concentration-dependent manner. }\end{array}$ & {$[88]$} \\
\hline Cinnamic acid & 5-10 mg/kg body weight & $\begin{array}{l}\text { In vivo and } \\
\text { in vitro }\end{array}$ & $\begin{array}{c}\downarrow \text { Blood glucose levels in a time- and } \\
\text { dose-dependent manner; } \\
\uparrow \text { Glucose tolerance; } \\
\uparrow \text { Glucose-stimulated insulin secretion } \\
\text { in isolated islets. }\end{array}$ & [89] \\
\hline
\end{tabular}

Legend: n.a.—not applicable; $\uparrow$ —ncrease; $\downarrow$ —Decrease.

The biological activities of P. avium cherries and their by-products may be due to the synergistic interactions of several bioactive compounds. Cao et al. [83] evaluated different phenolic fractions (anthocyanin, hydroxycinnamic acid, and flavonol-rich fractions) on the cellular glucose consumption-promotion in HepG2 cells. This study revealed that the hydroxycinnamic acid and flavonol-rich fractions were able to promote cellular glucose consumption by HepG2 cells [83], acting similarly to the hypoglycemic drugs (e.g., metformin) and insulin. Hydroxycinnamics, particularly caffeoylquinic acids, have been described as effective in blood glucose regulation through different mechanisms: (a) by competitive inhibition of the hydrolysis of glucose-6-phosphate (G6Pase) in the liver microsome [90], or (b) by induced AMPK phosphorylation, increasing glucose transporter 4 (GLUT4) expression and translocation to the plasma membrane in the muscle cell, and inhibition of hepatic G6Pase expression and activity [91]. In addition, the flavonols as quercetin and kaempferol showed similar activities in other experiments $[84,85]$. Concerning glucose absorption, phenolic compounds such as caffeic and ferulic acids, catechins, quercetin, and naringenin inhibit the sodium-dependent glucose cotransporter 1 (SGLT1) [83]. These compounds have previously been described in the P. avium fruit and its by-products (Table 4); thus, inhibiting this glucose transporter prevents glucose transport to insulin-responsive cells and avoids increased post-prandial glucose [92].

The anti-hyperglycemic activity of the P. avium fruit and its by-products was also evaluated in animal models. In a study developed by Lachin et al. [86], the protective effect of the ethanolic extract of cherry fruit was studied in alloxan-induced diabetic rats for 30 days. At a $200 \mathrm{mg} / \mathrm{kg}$ dose, the extract demonstrated a significant reduction of hyperglycemia and urinary microalbumin and an increase in urinary creatinine excretion [86]. Another report demonstrated that certain phenolic compounds such as diacylated anthocyanin, when administered orally, reduce the glycemia value induced by maltose ingestion in normal rats [93]. 
A study conducted by Noratto et al. [87] used obese diabetic $(d b / d b)$ mice fed with a diet supplemented with non-anthocyanin cherry phenolics. The authors demonstrated that these compounds exert protective effects in the liver and prevent hepatic inflammation in diabetic conditions through the decrease of fasting glucose levels [87]. This reduction can improve the pathological complications caused by hyperglycemia, mainly concerning oxidative stress. Moreover, it is known that high glucose levels can contribute to the increase of triglyceride-rich lipoproteins, and this study showed the antihyperlipidemic benefits of phenolic compounds [93].

Studies on isolated compounds present in P. avium fruits and their by-products, such as hydroxycinnamic acids, reduce the fasting glycemia and attenuate the increase of plasma glucose when administered intravenously to diabetic rats in both the streptozotocininduced and insulin-resistant models [88]. Moreover, chlorogenic acid, found in cherries and their stems, possesses anti-hyperglycemic activity [28]. Hafizur et al. [89] developed a study with cinnamic acid in non-obese type 2 diabetic rats. The results showed that the cinnamic acid (5 and $10 \mathrm{mg} / \mathrm{kg}$ of body weight) improved glucose tolerance in a dose-dependent manner and significantly enhanced glucose-stimulated insulin secretion in isolated islets [89].

\subsubsection{Human Studies and Clinical Trials}

Human studies are scarce and report only to the P. avium fruit. However, and as already described, the phenolic compounds existing in cherries and their by-products are similar. A study conducted by Kelley et al. [94] evaluated the effects of the consumption of sweet cherries ( $280 \mathrm{~g}$ per day) by healthy subjects ( 2 men and 16 women) on plasma lipids and markers of inflammation for 28 days. The authors verified that although the cherries showed a selective modulatory effect in proteins involved in the inflammatory process, they did not affect fasting blood glucose and insulin levels [94]. However, another study involving 19 diabetic women showed a reduction of glycemia and blood pressure, a decrease in levels of glycated hemoglobin ( $\mathrm{HbA} 1 \mathrm{c})$, and an improvement in body weight after ingestion of tart cherry juice (anthocyanins $720 \mathrm{mg}$ per day) for six weeks [95]. The anthocyanin content of the red fruits can positively influence the glycemic control verified in the studies based on the previous in vitro and animal studies, stimulating pancreatic cells to produce insulin [96]. Bozzetto et al. [97] conducted a randomized controlled trial, which showed that a diet rich in phenolics improves glucose metabolism in individuals at high risk of DM. Short-term supplementation with sweet and tart cherries in a single bout of resistance-trained individuals was able to reduce oxidative stress, proving to be an effective dietary supplement.

According to the studies mentioned above, the anti-hyperglycemic activity of phenolic compounds comprises reducing dietary carbohydrate digestion and consequently intestinal absorption, the modulation of enzymes involved in glucose metabolism, and the improvement of $\beta$-cell function and insulin action [19]. Thus, it is essential to identify the molecular mechanisms involved in these processes, develop new therapies to prevent, reverse, or delay the development and progression of DM through the use of bioactive compounds of the P. avium fruit and its by-products.

\section{Conclusions}

Sweet cherry is one of the most appreciated fruits worldwide, being recognized for its organoleptic properties and very rich in bioactive compounds. The production and processing of cherries produce large amounts of agro by-products such as leaves, stems, and flowers with a high potential for exploitation, representing tons of biowaste that can be valued. In this review, the most recent findings on the exploitation of P. avium by-products, namely their vegetal parts, were described. Cherry leaves, stems, and flowers proved to be an excellent promising source of bioactive compounds. Although the available literature is still limited, the data on the phenolic composition of cherry by-products are interesting. It is a good starting point for future studies in this area. Different extracts 
of cherry by-products are rich in phenolics, with phenolic acids and flavonoids as the main bioactive compounds. In addition, several studies reported that these extracts or compounds (isolated or conjugated) present in cherry by-products possess antioxidant and anti-hyperglycemic activities that are relevant in the prevention of oxidative stressrelated diseases such as DM. The mechanisms involved in the action of these bioactive compounds remain unclear and more studies are needed, but the present knowledge has opened the possibility of using the cherry by-products in new nutraceuticals and functional food, and in rethinking antidiabetic therapy. In conclusion, considering the traditional use of some cherry by-products and the biological potential already demonstrated by experimental studies, the demand for new therapies based on these bio-wastes justifies further scientific investment in order to produce more significant and deeper knowledge about these bio-wastes.

Author Contributions: Conceptualization, A.R.N., A.C.G., and L.R.S.; formal analysis and writingoriginal draft preparation, A.R.N.; writing—review and editing, A.R.N.; supervision, L.R.S., G.A., and A.F. All authors have read and agreed to the published version of the manuscript.

Funding: This research was funded by the Portuguese Foundation for Science and Technology (SFRH/BD/139137/2018 to Ana R. Nunes and 2020.04947.BD to Ana C. Gonçalves) and FEDER funds through the POCI-COMPETE 2020-Operational Programme Competitiveness and Internationalization in Axis I-Strengthening research, technological development, and innovation (Project POCI-01-0145-FEDER-007491), Operational Program of the Center (Project CENTRO-01-0247-FEDER017547). Graphical abstract created with BioRender.com (accessed on 7 April 2021).

Institutional Review Board Statement: Not applicable.

Informed Consent Statement: Not applicable.

Data Availability Statement: All data are reported in the manuscript.

Conflicts of Interest: The authors declare no conflict of interest.

\section{References}

1. Gonçalves, A.C.; Bento, C.; Silva, B.; Simões, M.; Silva, L.R. Nutrients, bioactive Compounda and Bioactivity: The Health Benefits of Sweet Cherries (Prunus avium L.). Curr. Nutr. Food Sci. 2018, 14, 1-20. [CrossRef]

2. Kelley, D.S.; Adkins, Y.; Laugero, K.D. A Review of the Health Benefits of Cherries. Nutrients 2018, 10, 368. [CrossRef]

3. Ferretti, G.; Bacchetti, T.; Belleggia, A.; Neri, D. Cherry antioxidants: From farm to table. Molecules 2010, 15, 6993-7005. [CrossRef]

4. Food and Agriculture Organization of the United Nations. FAOSTAT. Available online: http://www.fao.org/faostat/en/\#data/QC (accessed on 23 April 2021).

5. Gonçalves, A.C.; Rodrigues, M.; Santos, A.O.; Alves, G.; Silva, L.R. Antioxidant Status, Antidiabetic Properties and Effects on Caco-2 Cells of Colored and Non-Colored Enriched Extracts of Sweet Cherry Fruits. Nutrients 2018, 10, 1688. [CrossRef]

6. Gonçalves, A.C.; Bento, C.; Silva, B.; Silva, L.R. Sweet cherries from Fundão possess antidiabetic potential and protect human erythrocytes against oxidative damage. Food Res. Int. 2017, 95, 91-100. [CrossRef] [PubMed]

7. Jesus, F.; Gonçalves, A.C.; Alves, G.; Silva, L.R. Exploring the phenolic profile, antioxidant, antidiabetic and anti-hemolytic potential of Prunus avium vegetal parts. Food Res. Int. 2019, 116, 600-610. [CrossRef] [PubMed]

8. Ferreira-Santos, P.; Zanuso, E.; Genisheva, Z.; Rocha, C.M.R.; Teixeira, J.A. Green and Sustainable Valorization of Bioactive Phenolic Compounds from Pinus By-Products. Molecules 2020, 25, 2931. [CrossRef]

9. Yılmaz, F.M.; Görgüç, A.; Karaaslan, M.; Vardin, H.; Bilek, S.; Uygun, Ö.; Bircan, C. Sour Cherry By-products: Compositions, Functional Properties and Recovery Potentials-A Review. Crit. Rev. Food Sci. Nutr. 2019, 59, 1-49. [CrossRef] [PubMed]

10. Nunes, A.R.; Gonçalves, A.C.; Alves, G.; Falcão, A.; García-Viguera, C.; Moreno, D.A.; Silva, L.R. Valorisation of Prunus avium L. By-Products: Phenolic Composition and Effect on Caco-2 Cells Viability. Foods 2021, 10, 1185. [CrossRef]

11. Saavedra-Leos, M.Z.; Leyva-Porras, C.; Toxqui-Terán, A.; Espinosa-Solis, V. Physicochemical Properties and Antioxidant Activity of Spray-Dry Broccoli (Brassica oleracea var Italica) Stalk and Floret Juice Powders. Molecules 2021, 26, 1973. [CrossRef] [PubMed]

12. Bastos, C.; Barros, L.; Duenas, M.; Calhelha, R.C.; Queiroz, M.J.R.P.; Santos-Buelga, C.; Ferreira, I.C.F.R. Chemical characterisation and bioactive properties of Prunus avium L.: The widely studied fruits and the unexplored stems. Food Chem. 2015, 173, 1045-1053. [CrossRef]

13. Dziadek, K.; Kopeć, A.; Tabaszewska, M. Potential of sweet cherry (Prunus avium L.) by-products: Bioactive compounds and antioxidant activity of leaves and petioles. Eur. Food Res. Technol. 2019, 245, 763-772. [CrossRef]

14. Dziadek, K.; Kopeć, A.; Czaplicki, S. The petioles and leaves of sweet cherry (Prunus avium L.) as a potential source of natural bioactive compounds. Eur. Food Res. Technol. 2018, 244, 1415-1426. [CrossRef] 
15. Melini, V.; Melini, F.; Luziatelli, F.; Ruzzi, M. Functional Ingredients from Agri-Food Waste: Effect of Inclusion Thereof on Phenolic Compound Content and Bioaccessibility in Bakery Products. Antioxidants 2020, 9, 1216. [CrossRef] [PubMed]

16. Di Cagno, R.; Surico, R.F.; Minervini, G.; Rizzello, C.G.; Lovino, R.; Servili, M.; Taticchi, A.; Urbani, S.; Gobbetti, M. Exploitation of sweet cherry (Prunus avium L.) puree added of stem infusion through fermentation by selected autochthonous lactic acid bacteria. Food Microbiol. 2011, 28, 900-909. [CrossRef] [PubMed]

17. Hooman, N.; Mojab, F.; Nickavar, B.; Pouryousefi-Kermani, P. Diuretic effect of powdered Cerasus avium (cherry) tails on healthy volunteers. Pak. J. Pharm. Sci. 2009, 22, 381-383. [PubMed]

18. Gonçalves, A.C.; Campos, G.; Alves, G.; García-Viguera, C.; Moreno, D.A.; Silva, L.R. Physical and phytochemical compositon of 23 Portuguese sweet cherries as conditioned by variety (or genotype). Food Chem. 2021, 335, 127637. [CrossRef]

19. Dias, T.R.; Alves, M.G.; Casal, S.; Oliveira, P.F.; Silva, B.M. Promising Potential of Dietary (Poly)Phenolic Compounds in the Prevention and Treatment of Diabetes Mellitus. Curr. Med. Chem. 2017, 24, 334-354. [CrossRef]

20. Nunes, A.R.; Alves, M.G.; Tomas, G.D.; Conde, V.R.; Cristóvão, A.C.; Moreira, P.I.; Oliveira, P.F.; Silva, B.M. Daily consumption of white tea (Camellia sinensis (L.)) improves the cerebral cortex metabolic and oxidative profile in prediabetic Wistar rats. Br. J. Nutr. 2015, 113, 832-842. [CrossRef]

21. Wild, S.; Roglic, G.; Green, A.; Sicree, R.; King, H. Global prevalence of diabetes: Estimates for the year 2000 and projections for 2030. Diabetes Care 2014, 27, 1047-1053. [CrossRef]

22. Chen, L.; Magliano, D.J.; Zimmet, P.Z. The worldwide epidemiology of type 2 diabetes mellitus-Present and future perspectives. Nat. Rev. Endocrinol. 2011, 8, 228-236. [CrossRef]

23. Serra, A.T.; Duarte, R.O.; Bronze, M.R.; Duarte, C.M.M. Identification of bioactive response in traditional cherries from Portugal. Food Chem. 2011, 125, 318-325. [CrossRef]

24. Rosado, T.; Henriques, I.; Gallardo, E.; Duarte, A.P. Determination of melatonin levels in different cherry cultivars by highperformance liquid chromatography coupled to electrochemical detection. Eur. Food Res. Technol. 2017, 243, 1749-1757. [CrossRef]

25. Mulabagal, V.; Lang, G.A.; DeWitt, D.L.; Dalavoy, S.S.; Nair, M.G. Anthocyanin content, lipid peroxidation and cyclooxygenase enzyme inhibitory activities of sweet and sour cherries. J. Agric. Food Chem. 2009, 57, 1239-1246. [CrossRef] [PubMed]

26. Duarte, A.P.; Silva, B.M. Nutritional and Phytomedicinal Potential of Prunus avium L. In Natural Products: Research Reviews, 1st ed.; Daya Publishing House: New Delhi, India, 2016; pp. 185-202.

27. Linke, M.; Herppich, W.B.; Geyer, M. Green peduncles may indicate postharvest freshness of sweet cherries. Postharvest Biol. Technol. 2010, 58, 135-141. [CrossRef]

28. Aires, A.; Dias, C.; Carvalho, R.; Saavedra, M.J. Analysis of glycosylated flavonoids extracted from sweet-cherry stems, as antibacterial agents against pathogenic Escherichia coli isolates. Acta Biochim. Pol. 2017, 64, 265-271. [CrossRef] [PubMed]

29. Sargın, S.A.; Akçicek, E. An ethnobotanical study of medicinal plants used by the local people of Alaşehir (Manisa) in Turkey, J. Ethnopharmacol. 2013, 150, 860-874. [CrossRef] [PubMed]

30. Bown, D. Encyclopedia of Herbs and Their Uses; Dorling Kindersley: London, UK, 1995.

31. Martin, K.R.; Coles, K.M. Consumption of $100 \%$ Tart Cherry Juice Reduces Serum Urate in Overweight and Obese Adults. Curr. Dev. Nutr. 2019, 3, nzz011. [CrossRef]

32. Idolo, M.; Motti, R.; Mazzoleni, S. Ethnobotanical and phytomedicinal knowledge in a long-history protected area, the Abruzzo, Lazio and Molise National Park (Italian Apennines). J. Ethnopharmacol. 2010, 127, 379-395. [CrossRef]

33. Alarcón, R.; Pardo-de-Santayana, M.; Priestley, C.; Morales, R.; Heinrich, M. Medicinal and local food plants in the south of Alava(Basque Country, Spain). J. Ethnopharmacol. 2015, 176, 207-224. [CrossRef]

34. Luna-Vázquez, F.J.; Ibarra-Alvarado, C.; Rojas-Molina, A.; Rojas-Molina, J.I.; Yahia, E.M.; Rivera-Pastrana, D.M.; Rojas-Molina, A.; Zavala-Sánchez, M.Á. Nutraceutical value of black cherry Prunus serotina Ehrh. fruits: Antioxidant and antihypertensive properties. Molecules 2013, 18, 14597-14612. [CrossRef]

35. Vinagre, C.; Vinagre, S.; Carrilho, E. The use of medicinal plants by the population from the Protected Landscape of "Serra de Montejunto", Portugal. J. Ethnobiol. Ethnomed. 2019, 15, 30. [CrossRef] [PubMed]

36. Tutulescu, F.; Boruzi, A.I.; Nour, V. Antibacterial activity of walnut leaves and sweet cherry stems in cooked pork patties. South West. J. Hortic. Biol. Environ. 2019, 10, 65-75.

37. Sulaiman, G.M.; Al-Amiery, A.A.H.; Mohammed, A.A.; Al-Temimi, A.A. The Effect of Cherry Sticks Extract on the Levels of Glycoproteins in Alloxan-Induced Experimental Diabetic Mice. Ann. Clin. Lab. Sci. 2012, 42, $34-41$.

38. Beckman, C.H. Phenolic-storing cells: Keys to programmed cell death and periderm formation in wilt disease resistance and in general defence responses in plants? Physiol. Mol. Plant. Pathol. 2000, 57, 101-110. [CrossRef]

39. Alasalvar, C.; Grigor, J.M.; Zhang, D.; Quantick, P.C.; Shahidi, F. Comparison of volatiles, phenolics, sugars, antioxidant vitamins, and sensory quality of different colored carrot varieties. J. Agric. Food Chem. 2001, 49, 1410-1416. [CrossRef]

40. Tsao, R. Chemistry and biochemistry of dietary polyphenols. Nutrients 2010, 2, 1231-1246. [CrossRef]

41. Silveira, A.C.; Dias, J.P.; Santos, V.M.; Oliveira, P.F.; Alves, M.G.; Rato, L.; Silva, B.M. The Action of Polyphenols in Diabetes Mellitus and Alzheimer's Disease: A Common Agent for Overlapping Pathologies. Curr. Neuropharmacol. $2019,17,290-613$. [CrossRef] [PubMed]

42. Mattila, P.; Hellstrom, J.; Torronen, R. Phenolic acids in berries, fruits, and beverages. J. Agric. Food Chem. 2006, 54, 7193-7199. [CrossRef] 
43. Kelebek, H.; Selli, S. Evaluation of chemical constituents and antioxidant activity of sweet cherry (Prunus avium L.) cultivars. Int. J. Food Sci. Tecnol. 2011, 46, 2530-2537. [CrossRef]

44. Martini, S.; Conte, A.; Tagliazucchi, D. Phenolic compounds profile and antioxidant properties of six sweet cherry (Prunus avium) cultivars. Food Res. Int. 2017, 97, 15-26. [CrossRef]

45. Jakobek, L.; Šeruga, M.; Voća, S.; Šindrak, Z.; Dobričević, N. Flavonol and phenolic acid composition of sweet cherries (cv. Lapins) produced on six different vegetative rootstocks. Sci. Hortic. 2009, 123, 23-28. [CrossRef]

46. Cook, N.C.; Samman, S. Flavonoids-Chemistry, metabolism, cardioprotective effects, and dietary sources. J. Nutr. Biochem. 1996, 7, 66-76. [CrossRef]

47. Balasundram, N.; Sundram, K.; Samman, S. Phenolic compounds in plants and agri-industrial by-products: Antioxidant activity, occurrence, and potential uses. Food Chem. 2006, 99, 191-203. [CrossRef]

48. Heim, K.E.; Tagliaferro, A.R.; Bobilya, D.J. Flavonoid antioxidants: Chemistry, metabolism and structure-activity relationships. J. Nutr. Biochem. 2002, 13, 572-584. [CrossRef]

49. Erlund, I. Review of the flavonoids quercetin, hesperetin, and naringenin. Dietary sources, bioactivities, bioavailability, and epidemiology. Nutr. Res. 2004, 24, 851-874. [CrossRef]

50. Milbury, P.E.; Chen, C.-Y.; Dolnikowski, G.G.; Blumberg, J.B. Determination of Flavonoids and Phenolics and Their Distribution in Almonds. J. Agric. Food Chem. 2006, 54, 5027-5033. [CrossRef]

51. Rice-Evans, C.; Miller, N.; Paganga, G. Structure-antioxidant activity relationships of flavonoids and phenolic acids. Free Radic Biol Med. 1996, 20, 933-956. [CrossRef]

52. Hernandez-Montes, E.; Pollard, S.E.; Vauzour, D.; Jofre-Montseny, L.; Rota, C.; Rimbach, G.; Weinberg, P.D.; Spencer, J.P.E. Activation of Glutathione Peroxidase via Nrf1 Mediates Genistein's Protection Against Oxidative Endothelial Cell Injury. Biochem. Biophys Res. Commun. 2006, 346, 851-859. [CrossRef] [PubMed]

53. Willits, M.G.; Giovanni, M.; Prata, C.R.T.N.; Kramer, V.M.; De Luca, V.; Steffens, J.C.; Graser, G. Bio-fermentation of modified flavonoids: An example of in vivo diversification of secondary metabolites. Phytochemistry 2004, 65, 31-41. [CrossRef]

54. Ross, J.A.; Kasum, C.M. Dietary flavonoids: Bioavailability, metabolic effects, and safety. Annu. Rev. Nutr. 2002, 22, 19-34. [CrossRef] [PubMed]

55. Naczk, M.; Shahidi, F. Phenolics in cereals, fruits and vegetables: Occurrence, extraction and analysis. J. Pharm. Biomed. Anal. 2006, 41, 1523-1542. [CrossRef]

56. Bauer, H.; Treutter, D.; Schmid, P.P.S.; Schmitt, E.; Feucht, F. Specific accumulation of o-diphenols in stressed leaves of Prunus avium. Phytochmeistry 1989, 28, 1363-1364. [CrossRef]

57. Mo, Y.Y.; Geibel, M.; Bonsall, R.F.; Gross, D.C. Analysis of Sweet cherry (Prunus avium L.) Leaves for Plant Signal Molecules That Activate the syrB Gene Required for Synthesis of the Phytotoxin, Syringomycin, by Pseudomonas syringae pv syringae. Plant. Physiol. 1995, 107, 603-612. [CrossRef] [PubMed]

58. Kim, D.-O.; Heo, H.J.; Kim, Y.J.; Yang, H.S.; Lee, C.Y. Sweet and sour cherry phenolics and their protective effects on neuronal cells. , J. Agric. Food Chem. 2005, 53, 9921-9927. [CrossRef]

59. Corradini, E.; Foglia, P.; Giansanti, P.; Gubbiotti, R.; Samperi, R.; Lagana, A. Flavonoids: Chemical properties and analytical methodologies of identification and quantitation in foods and plants. Nat. Prod. Res. 2011, 25, 469-495. [CrossRef]

60. Neveu, V.; Perez-Jimenez, J.; Vos, F.; Crespy, V.; Chaffaut, L.; Mennen, L.; Knox, C.; Eisner, R.; Cruz, J.; Wishart, D.; et al. Phenol-Explorer: An online comprehensive database on polyphenol contents in foods. Database 2010, 2010, bap024. [CrossRef]

61. Anhê, F.F.; Desjardins, Y.; Pilon, G.; Dudonne, S.; Genovese, M.I.; Lajolo, F.M.; Marette, A. Polyphenols and type 2 diabetes: A prospective review. PharmaNutrition 2013,1, 105-114. [CrossRef]

62. Osakabe, N. Flavan 3-ols improve metabolic syndrome risk factors: Evidence and mechanisms. J. Clin. Biochem. Nutr. 2013, 52, 186-192. [CrossRef]

63. Khanbabaee, K.; van Ree, T. Tannins: Classification and Definition. Nat. Prod. Rep. 2001, 18, 641-649. [CrossRef]

64. Serradilla, M.J.; Hernández, A.; López-Corrales, M.; Ruiz-Moyano, S.; Córdoba, M.; Martín, A. Compositon of the cherry (Prunus avium L. and Prunus cerasus L.; Rosaceae). In Nutritional Composition of Fruit Cultivars; Simmonds, M.J.S., Preedy, V.R., Eds.; Academic Press: London, UK, 2016; pp. 127-147.

65. Castañeda-Ovando, A.; Pacheco-Hernández, M.L.; Páez-Hernández, M.E.; Rodríguez, J.A.; Gálan-Vidal, C.A. Chemical studies of anthocyanins: A review. Food Chem. 2009, 113, 859-871. [CrossRef]

66. Chockchaisawasdee, S.; Golding, J.B.; Vuong, Q.V.; Papoutsis, K.; Stathopoulos, C.E. Sweet cherry: Composition, postharvest preservation, processing and trends for its future use. Trends Food Sci. Technol. 2016, 55, 72-83. [CrossRef]

67. Pascual-Teresa, S.; Moreno, D.A.; García-Viguera, C. Flavanols and Anthocyanins in Cardiovascular Health: A Review of Current Evidence. Int. J. Mol. Sci. 2010, 11, 1679-1703. [CrossRef] [PubMed]

68. Ballistreri, G.; Continella, A.; Gentile, A.; Amenta, M.; Fabroni, S.; Rapisarda, P. Fruit quality and bioactive compounds relevant to human health of sweet cherry (Prunus avium L.) cultivars grown in Italy. Food Chem. 2013, 140, 630-638. [CrossRef]

69. Jesus, F.; Gonçalves, A.C.; Alves, G.; Silva, L.R. Health Benefits of Prunus avium Plant Parts: An Unexplored Source Rich in Phenolic Compounds. Food Rev. Int. 2020. [CrossRef] 
70. Asmat, U.; Abad, K.; Ismail, K. Diabetes mellitus and oxidative stress-A concise review. Saudi Pharm. Soc. 2016, 24, 547-553. [CrossRef]

71. Leyva-Porras, C.; Román-Aguirre, M.; Cruz-Alcantar, P.; Pérez-Urizar, J.T.; Saavedra-Leos, M.Z. Application of Antioxidants as an Alternative Improving of Shelf Life in Foods. Polysaccharides 2021, 2, 594-607. [CrossRef]

72. Singh, B.; Singh, J.P.; Kaur, A.; Singh, N. Phenolic composition, antioxidant potential and health benefits of citruspee. Food 2020, 132, 109114.

73. Afonso, S.; Oliveira, I.V.; Meyer, A.S.; Aires, A.; Saavedra, M.J.; Gonçalves, B. Phenolic Profile and Bioactive Potential of Stems and Seed Kernels of Sweet Cherry Fruit. Antioxidants 2020, 9, 1295. [CrossRef]

74. Prvulovic, D.; Popovic, M.; Malenčić, D.; Ljubojevic, M.; Ognjanov, V. Phenolic compounds in sweet cherry (Prunus avium L.) petioles and their antioxidant properties. Res. J. Agric. Sci. 2011, 43, 198-202.

75. Aires, A.; Marrinhas, E.; Carvalho, R.; Dias, C.; Saavedra, M.J. Phytochemical composition and antibacterial activity of hydroalcoholic extracts of Pterospartum tridentatum and mentha pulegium against Staphylococcus aureus isolates. Biomed. Res. Int. 2016, 2016. [CrossRef] [PubMed]

76. Lin, D.; Xiao, M.; Zhao, J.; Li, Z.; Xing, B.; Li, X.; Kong, M.; Li, L.; Zhang, Q.; Liu, Y.; et al. An Overview of Plant Phenolic Compounds and Their Importance in Human Nutrition and Management of Type 2 Diabetes. Molecules 2016, 21, 1374. [CrossRef] [PubMed]

77. Giacco, F.; Brownlee, M. Oxidative stress and diabetic complications. Circ. Res. 2010, 107, 1058-1070. [CrossRef] [PubMed]

78. Yilmazer-Musa, M.; Griffith, A.M.; Michels, A.J.; Schneider, E.; Frei, B. Inhibition of $\alpha$-Amylase and $\alpha$-Glucosidase Activity by Tea and Grape Seed Extracts and their Constituent Catechins. J. Agric. Food Chem. 2012, 60, 8924-8929. [CrossRef] [PubMed]

79. Ibitoye, O.B.; Ajiboye, T.O. Dietary phenolic acids reverse insulin resistance, hyperglycaemia, dyslipidaemia, inflammation and oxidative stress in high-fructose diet-induced metabolic syndrome rats. Arch. Physiol. Biochem. 2018, 124, 410-417. [CrossRef]

80. Yin, Z.; Wang, J.; Gu, X.; Gu, H.; Kang, W. Antioxidant and a-glucosidase inhibitory activity of red raspberry (Harrywaters) fruits in vitro. Afr. J. Pharm. Pharmacol. 2012, 6, 3118-3123. [CrossRef]

81. Mandave, P.; Rani, S.; Kuvalekar, A.; Ranjekar, P.K. Antiglycation, antioxidant and antidiabetic activity of mature Strawberry (Fragaria $\times$ ananassa) fruits. Int. J. Appl. Biol. Pharm. Technol. 2013, 4, 168.

82. Akkarachiyasit, S.; Yibchok-Anun, S.; Wacharasindhu, S.; Adisakwattana, S. In Vitro Inhibitory Effects of Cyanidin-3-rutinoside on Pancreatic $\alpha$-Amylase and Its Combined Effect with Acarbose. Molecules 2011, 16, 2075-2083. [CrossRef]

83. Cao, J.; Li, X.; Liu, Y.; Leng, F.; Li, X.; Sun, C.; Chen, K. Bioassay-based isolation and identification of phenolics from sweet cherry that promote active glucose consumption by HepG2 cells. J. Food Sci. 2015, 80, C234-C240. [CrossRef]

84. Fang, X.-K.; Gao, J.; Zhu, D.-N. Kaempferol and quercetin isolated from Euonymus alatus improve glucose uptake of 3T3-L1 cells without adipogenesis activity. Life Sci. 2008, 82, 615-622. [CrossRef]

85. Chen, Q.C.; Zhang, W.Y.; Jin, W.; Lee, I.S.; Min, B.-S.; Jung, H.-J.; Na, M.; Lee, S.; Bae, K. Flavonoids and isoflavonoids from Sophorae Flos improve glucose uptake in vitro. Planta Med. 2010, 6, 79-81. [CrossRef] [PubMed]

86. Lachin, T.; Reza, H. Anti diabetic effect of cherries in alloxan induced diabetic rats. Recent Pat. Endocr. Metab. Immune Drug Discov. 2012, 6, 67-72. [CrossRef]

87. Noratto, G.D.; Lage, N.N.; Chew, B.P.; Mertens-Talcott, S.U.; Talcott, S.T.; Pedrosa, M.L. Non-anthocyanin phenolics in cherry (Prunus avium L.) modulate IL-6, liver lipids and expression of PPAR $\delta$ and LXRs in obese diabetic (db/db) mice. Food Chem. 2018, 266, 405-414. [CrossRef]

88. Hsu, F.L.; Chen, Y.C.; Cheng, J.T. Caffeic Acid as Active Principle From the Fruit of Xanthium Strumarium to Lower Plasma Glucose in Diabetic Rats. Planta Med. 2000, 66, 228-230. [CrossRef] [PubMed]

89. Hafizur, R.M.; Hameed, A.; Shukrana, M.; Raza, S.A.; Chishti, S.; Kabir, N.; Siddiqui, R.A. Cinnamic acid exerts anti-diabetic activity by improving glucose tolerance in vivo and by stimulating insulin secretion in vitro. Phytomedicine 2015, 22, 297-300. [CrossRef]

90. Henry-Vitrac, C.; Ibarra, A.; Roller, M.; Mérillon, J.-M.; Vitrac, X. Contribution of chlorogenic acids to the inhibition of human hepatic glucose-6-phosphatase activity in vitro by Svetol, a standardized decaffeinated green coffee extract. J. Agric. Food Chem. 2010, 58, 4141-4144. [CrossRef] [PubMed]

91. Ong, K.W.; Hsu, A.; Tan, B.K.H. Chlorogenic acid stimulates glucose transport in skeletal muscle via AMPK activation: A contributor to the beneficial effects of coffee on diabetes. PLOS ONE 2012, 7, e32718. [CrossRef]

92. Dias, T.R.; Bernardino, R.L.; Meneses, M.J.; Sousa, M.; Sá, R.; Alves, M.G.; Silva, B.M.; Oliveira, P.F. Emerging Potential of Natural Products as an Alternative Strategy to Pharmacological Agents Used Against Metabolic Disorders. Curr. Drug Metab. 2016, 17, 582-597. [CrossRef]

93. Matsui, T.; Ebuchi, S.; Kobayashi, M.; Fukui, K.; Sugita, K.; Terahara, N.; Matsumoto, K. Anti-hyperglycemic Effect of Diacylated Anthocyanin Derived from Ipomoea Batatas Cultivar Ayamurasaki can be Achieved Through the Alpha-Glucosidase Inhibitory Action. J. Agric. Food Chem. 2002, 50, 7244-7248. [CrossRef]

94. Kelley, D.S.; Rasooly, R.; Jacob, R.A.; Kader, A.A.; Mackey, B.E. Consumption of Bing sweet cherries lowers circulating concentrations of inflammation markers in healthy men and women. , J. Nutr. 2006, 136, 981-986. [CrossRef] [PubMed]

95. Garrido, M.; González-Gómez, D.; Lozano, M.; Barriga, C.; Paredes, S.D.; Rodríguez, A.B. A Jerte valley cherry product provides beneficial effects on sleep quality. Influence on aging. J. Nutr. Heal. Aging. 2013, 17, 553-560. [CrossRef] [PubMed] 
96. Jayaprakasam, B.; Vareed, S.K.; Olson, L.K.; Nair, M.G. Insulin secretion by bioactive anthocyanins and anthocyanidins present in fruits. J. Agric. Food Chem. 2005, 53, 28-31. [CrossRef] [PubMed]

97. Bozzetto, L.; Annuzzi, G.; Pacini, G.; Costabile, G.; Vetrani, C.; Vitale, M.; Griffo, E.; Giacco, A.; De Natale, C.; Cocozza, S.; et al. Polyphenol-rich diets improve glucose metabolism in people at high cardiometabolic risk: A controlled randomised intervention trial. Diabetologia 2015, 58, 1551-1560. [CrossRef] [PubMed] 